\title{
Title: A Chemical and Ecological Assessment into Elemental Loading from Ford Crossings in Ashdown Forest, Sussex, United Kingdom
}

Keywords: freshwater quality, biomonitoring, vehicular wash-off, Road run-off, metal loading, ford crossings

Corresponding Author: Mr. Phillip Martyn Colyer, MSc

Corresponding Author's Institution: University of Portsmouth

First Author: Phillip Martyn Colyer, MSc

Order of Authors: Phillip Martyn Colyer, MSc; Mohammad A Hoque; Mike Fowler

Abstract: Numerous studies have identified the issue of road surface runoff as a source of contamination into waterways but the impact of vehicular wash-off is less well understood. A ford crossing provides a pathway for vehicle-derived contaminants emanating from both road surface runoff and vehicular wash-off into a river system. Twyford Lane Ford (Ford 1) and Birchgrove Lane Ford (Ford 2), located ca. 600m apart on a tributary of the River Ouse in Sussex (UK), were the focus of this study. A combination of biomonitoring (assessment of benthic macroinvertebrates) and chemical assessments of water and sediments has been undertaken to determine any detrimental impacts, such as a lack in biodiversity, resulting from the ford crossings. Sediment concentrations of chromium $(\mathrm{Cr} 3+)$, lead (Pb) and zinc ( $\mathrm{Zn})$ were generally elevated at Ford 1, attenuating at sampling points between the fords to then peak at Ford 2 . However, soil organic matter (SOM) and sediment particle size were seen to have an influence on elemental concentrations, in general with an increase in elemental concentrations associated with a higher percentage of fine-grained sediments $(\leq 63 \mu \mathrm{m})$. Elevated concentrations of $\mathrm{Zn}$ and magnesium (Mg) were identified within water samples taken during a precipitation event following a prolonged dry period. The biomonitoring results found reduced BMWP (Biological Monitoring Working Party) scores at positions close to the ford crossings, and where the stream was in proximity to the roadside. Sensitive Ephemeroptera were largely absent at sampling points closest to the fords, which is likely to be associated with elevated $\mathrm{Zn}$. The results suggest that careful consideration should be applied when selecting crossing points over sensitive waters. 


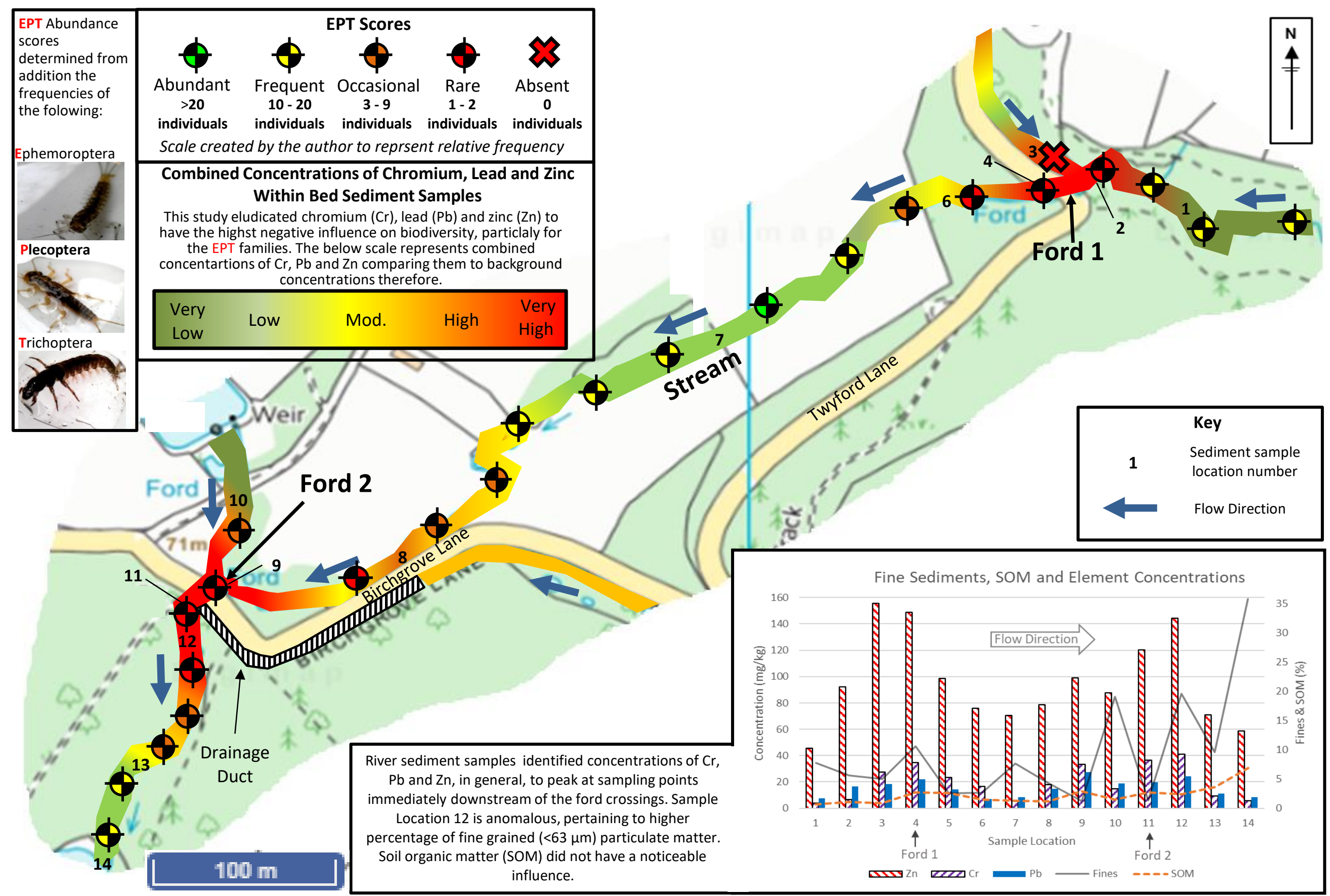


Water resources are coming under increasing pressure from human development, particularly in heavily populated areas such as South-East England. Roadways provide a linear source of contamination, both into the atmosphere and onto the neighbouring land and waterways. The UK Department for Transport (2016) estimated the total road length in Great Britain to be 246,000 miles with 2214 ford river crossings. Such fords provide a convergence point for traffic-derived contaminants to enter waterways via vehicular wash off, road surface runoff or from airborne particulate matter. Sebastiao et.al. (2017) identified first flush run-off events, i.e. a rainfall event preceded by a prolonged dry period, as a major contribution to metal loading into waterways. Vehicle-derived trace metals and metalloids delivered into the environment emanate from a variety of sources: for example, dissolved arsenic (As), cadmium (Cd), copper ( $\mathrm{Cu}$ ), $\mathrm{Pb}$, nickel (Ni) and $\mathrm{Zn}$ from oils and lubricants and Cu from brake pad linings and tyres (Johnsson et al., 2002; Davis et al., 2001). Galvanised metals on vehicles provide a source of $\mathrm{Zn}$ and Cd (Beasley \& Kneale, 2003). Additionally, applying weed killers on roadsides can provide sources of $\mathrm{As}, \mathrm{Cd}$ and $\mathrm{Cu}$ (Beasley \& Kneale, 2003).

A study by Revitta et al. (2014) identified land use type as the main contributing factor to metal loading in river systems. Urbanised areas were associated with increased levels of metals, predominantly derived from vehicle and road surface wear. Vehicles are sources of particulate matter pollution, often deposited on road surfaces to be subsequently washed into neighbouring drainage systems or local waterways (Adamiec at al., 2016). The main contaminants of concern associated with vehicles are heavy metals and fuels. The Department of Environment (DoE) industry profiles (CL:AIRE 2018) do not specifically cover roadways, but profiles for garages and filling stations, and transport and haulage centres, 
highlight vehicle-derived contaminants. Table S1 in the supplementary information (SI) highlights the contaminants that are likely to find their way into water systems in proximity to roadways. Metals are of particular concern and are becoming more prevalent due to their widespread use and accumulative behaviours (Kang et al., 2017). Heavy metals have the propensity to adsorb to sediments, which thus provide a sink or, through the process of desorption, a subsequent source of metal contamination in waters.

The loading of contaminants into an ecosystem is an arresting factor for ecological succession which interrupts biological resources, including agricultural and fishery products (Amiard-Triquet et al., 2011). Identifying an abundance of tolerant species gives insights into sustainability of the biodiversity and indicates ecosystem performance, potentially giving warning, and thus enabling some form of mitigation. A pollution event into a stream, e.g. an influx of contaminants emanating from a point source, can, and often does, create a dead zone within the river system which effectively creates fragmented habitat zones. This stops migratory paths and, particularly for species that live the entirety of their lives in the river, arrests their dispersal and colonisation opportunities. Debenski and Holt (2000) identified that species which are displaced due to detrimental anthropogenic pressures tend to accumulate in the remaining patches of "better quality" habitat. However, after an initial abundance peak, it was found that population size soon regressed to the mean (termed a relaxation period, Primack, 2006) due to further dispersal limitations, inter/intraspecies relationships, genetic pressure and increased vulnerability to catastrophic events. Riparian ecosystems, one of the most diverse zones in the UK, interact with the landscape around them and often provide the most critical nutrient and trophic interactions in an ecosystem (Naiman et al., 2005). Therefore, their preservation should be sought with priority. 
Lauma \& Rainbow (2010) argue that trace metal contamination is poorly understood, attributing this to the lack of application of toxicity data to the complexities of natural water systems and biological communities. Wright et al. (1997) state that biological monitoring is required to complement chemical monitoring, as a biotic appraisal gives a means to determine the consequences of environmental stress. Therefore, a combination of both methods should give comprehensive insight to the chemical regime of a water body, helping to elucidate the governing factors. Because of the ever-increasing reliance on vehicles, and consequent environmental pressures, this study aims to establish the impact of vehicular wash-off and surface runoff emanating from ford river crossings on the elemental and macroinvertebrate composition of the adjacent stream, located within the Birchgrove Area of the Ashdown Forest, East Sussex (Figure 1). The study integrates geochemistry, fluvial dynamics, geomorphology and ecology - thus providing a holistic appreciation of metal contamination often missing from many works, in addition to providing rare insight into the effects that ford crossings have on the local water environment.

\section{Description of the study site}

The site occupies a section of a tributary of the River Ouse, located in a shallow valley comprising campestral, sylvan and agrarian land - near Twyford Farm in the Ashdown Forest, Sussex (National Grid Ref. for central point: 539940, 130620). Local topography slopes gently down from the north-east to the south-west with elevation ranging from 70 to $100 \mathrm{~m}$ above sea level.

The north-eastern section of the study site (Ford 1) is located within an area of deciduous woodland, which turns into coniferous silviculture to the south-east (Figure 1). As the 
stream courses toward the south-west, it is flanked on both sides by sheep pasture, part of Twyford Farm. Hydrophilic lower order plants and trees occupy the banks of the stream as it traverses the grass pasture. Flowing south-west past Birchgrove Lane (Ford 2) the stream courses into privately-owned land forming part of Hurstwood Farm. This area comprises unkempt grass and ruderals with several broadleaf standards. Land to the south-east of Hurstwood Farm supports deciduous woodland.

Figure 1 shows the site location, and sample stations. Figure S1 in the SI shows site topography. The main channel is joined immediately upstream of Ford 1 by a minor channel (Minor Stream 1 [MS1]) which flows south-east to form a confluence at Ford 1 . MS1 is cut adjacent to Twyford Lane to assist with road drainage. Minor Stream 2 (MS2) joins the main channel immediately upstream of Ford 2. MS2 feeds from a fishing lake located south of Grinstead Wood. Historic and contemporary mapping identifies a ford crossing on MS2, however, the site walkover identified this as a culvert running under a track to which vehicular access was not permitted. Minor Stream 3 (MS3) is another cutting into the roadside, that runs alongside Birchgrove Lane before entering MDPE ducting and then draining downstream of Ford 2. Both MS1 and MS3 are ephemeral and were dry on several visits.

With reference to online mapping published by the British Geological Society, the geology underlying the site comprises interbedded sandstones and siltstones of the Ashdown Formation, part of the Lower Cretaceous Wealden Group . However, superficial alluvium occupies the streambed and banks. It is assumed that groundwater flows southward, following the course of the river. Intermittent clay horizons may also give rise to perched groundwater. Likely coefficients of permeability, with reference to Knappett and Craig 
95 (2012), are $10^{-5}$ to $10^{-8} \mathrm{~m} / \mathrm{s}$ for alluvial deposits, $10^{-7}$ to $10^{-9} \mathrm{~m} / \mathrm{s}$ for the clays and silts of the

96

97

Ashdown Beds and $10^{-2}$ to $10^{-6} \mathrm{~m} / \mathrm{s}$ for the sandy horizons.

Twyford Lane and Birch Grove Road are unclassified minor roads that cross the stream via two fords and thus represent potential sources of contamination of stream water. Traffic counts were conducted at hourly intervals on various days and times (Table S2 - SI) to obtain an estimate of traffic density - an average of 144 crossings per day at Twyford Lane (Ford 1) and 223 at Birchgrove Lane (Ford 2).

Several historic discharge consents, mostly for sewage/effluent, have been identified (Table S3 - SI) within or upstream of the site. Said discharges may lead to the realise of adsorbed metals, or to an increase of their adsorption. Additionally, the influx of nutrients may lead to reduced dissolved oxygen which would impact stream ecology. However, since the identified discharge consents date back to 2006 and 1961, the stream system has had ample time to recover.

A conceptual site model (Figure 2) identifies several source-pathway-receptor (SPR) linkages. Humans and their pets are recognised as receptors through direct contact with waters and/or sediments potentially impacted by heavy metals. Several site visits identified humans and dogs playing and bathing in the waters of the fords. Nevertheless, human risk is considered to be low. On the other hand, there exists significant potential risk to ecology, both faunal and floral.

\section{Methods and Materials}

\subsection{Soil and water sampling}

17 samples of each, for water and near surface sediments, were collected (Figure 1), at locations recorded using handheld GPS in reference to WGS84 datum (Tables S4 and S5 - SI). 
Selection of sample sites reflected distance from the ford crossings, starting with a control sample at sample point 1 (SP1). Water and sediment samples were taken immediately adjacent to the upstream and downstream section of the fords and at intervals downstream. Other sampling positions were selected to determine attenuation characteristics; SP17 was specifically selected to delineate any influence from the historic discharge consent. Finally, five near surface soil samples (between $0.20-0.50 \mathrm{~m} \mathrm{bgl}$ ) were taken within the surrounding area to constrain local background metal concentrations.

Water samples were collected on two separate occasions, during a prolonged dry period $(12 / 05 / 18)$ and during a precipitation event (30/07/18). Because the stream is likely spring fed, it is likely unlikely that it dries out - further backed up by sampling taking place during the summer. Water samples were collected in a $1 \mathrm{~L}$ amber glass bottle and held in temperature-controlled storage (cool box with ice packs). Dissolved oxygen (DO) was measured on site using a CHEMets DO kit and Electrical Conductivity was measured using a portable Hanna EC meter. Stream discharge measurements were estimated using a float over a $10 \mathrm{~m}$ reach. Metal concentrations were subjected to two tailed t-tests to identify the significance of first flush runoff.

Sediment samples were collected, from downstream to upstream to avoid cross contamination, using a plastic trowel cleaned prior to each location. Three samples of sediment were taken at the base of each bank and at the bed under the thalweg, these were combined to form a composite sample, from no deeper than $50 \mathrm{~mm}$ depth - the optimum oxidising and most biologically active zone (Naiman et al., 2005). Once collected, sediment was placed in a $500 \mathrm{ml}$ amber jar and stored in a cool box. Additionally, 
approximately $1 \mathrm{~kg}$ of sediment was placed in a plastic soil bag for determination of particle

141 size distribution (PSD).

142 Distances of sampling locations from the nearest road and ford crossing were measured 143 using a GPS and ArcGIS. The results were used to calculate Pearson's correlation coefficients 144 to assess the influence that roads and ford crossings had on metal concentrations.

\subsection{Laboratory Analysis}

Samples were sent to UKAS accredited laboratory - The Environmental Laboratory (E-lab), St. Leonards-on-Sea, East Sussex - for chemical testing. The analysis suite comprised zootoxic and phytotoxic elements (As, $\mathrm{Cd}, \mathrm{Cr}$, $\mathrm{Cu}$, mercury $(\mathrm{Hg})$, magnesium $(\mathrm{Mg})$, manganese (Mn), molybdenum (Mo), $\mathrm{Pb}$ and $\mathrm{Zn}$ ) associated with vehicular runoff/wash-off.

Extractable/dissolved metals were determined using ICP-MS whilst hexavalent $\mathrm{Cr}$ was measured using colorimetry. The methodology statements (including estimates of accuracy and precision) from E-lab are presented in the SI.

Sediment particle size distribution (PSD) tests were carried out at a UKAS accredited geotechnical laboratory - K4 Soils Laboratory, Watford, Hertfordshire - in accordance with British Standard 1377-2 (1990). Samples were passed through a series of sieves ranging from $125 \mathrm{~mm}$ down to $63 \mu \mathrm{m}$, the size ranges were then quantified by percentage of total weight.

\subsection{Ecological Sampling}

Kick sampling was selected as it is the most widespread and well-developed methodology (Mason, 2002), is often applied in order to comply with policy-driven guidelines (Carter and Resh, 2011) and has the lowest resource requirement. Sampling locations were identified using GPS, once identified one person (the kicker) stands $3 \mathrm{~m}$ upstream of the other (the 
netter). The kicker proceeds to manoeuvre in a zigzag pattern kicking up the sediment, causing as much disturbance as possible (the zigzag pattern helps ensure that the different habitats are disturbed) whilst the second person nets the dislodged invertebrates flowing down the stream. The net had a $250 \mathrm{~mm} \times 250 \mathrm{~mm}$ frame with a $900 \mu \mathrm{m}$ mesh net $(275 \mathrm{~mm}$ deep) and a $1.60 \mathrm{~m}$ handle. The invertebrates were then placed into a sampling tray and taken back to the van (serving as a mini-lab) for identification and abundance. An electronic microscope with $1000 \mathrm{x}$ magnification was used to aid with identification and to take photographs. All aquatic invertebrates were returned to their relative locations once identification had been completed. The presence and abundance of species were then used to assign a BWMP score and to determine the relative abundance of certain species.

BMWP scores for taxa can be found in Henderson, 2006 pp.127. With reference to the Ouse and Adur Rivers Trust, the classifications for BMWP scores are $>130$ - Very Good, $81-130-$ Good, 51 - 80 Fair, 11-50 - Poor, and 0 - 10 Very Poor.

\subsection{Results}

\subsection{Chemical Composition of Water}

As, $\mathrm{Mo}, \mathrm{Cr}, \mathrm{Pb}, \mathrm{Cu}$ and $\mathrm{Hg}$ along with hexavalent $\mathrm{Cr}$ were uniformly below their respective detection limits $(5 \mu \mathrm{g} / \mathrm{L}$ for As, Mo, $\mathrm{Cr}$ and $\mathrm{Cu}, 1 \mu \mathrm{g} / \mathrm{L}$ for $\mathrm{Pb}, 0.1 \mu \mathrm{g} / \mathrm{L}$ for $\mathrm{Hg}$ and $100 \mu \mathrm{g} / \mathrm{L}$ for hexavalent $\mathrm{Cr}$ ).

Zn levels in water were generally below the detection limit $(5 \mu \mathrm{g} / \mathrm{L})$ (Figure 3). However, peak concentrations, particularly after the precipitation event, were shown at sampling locations immediately downstream of the fords, SP4 and SP11 $(22 \mu \mathrm{g} / \mathrm{L}$ and $38 \mu \mathrm{g} / \mathrm{L}$ respectively). $\mathrm{Zn}$ concentrations returned to levels below the detection limit with increased distance downstream from both fords. 
Mg levels generally declined from SP1 to SP14 in dry conditions along the main stream (Figure 3), suggesting a source upstream from SP1. No outliers were observed in dry conditions. A significant increase was identified after the precipitation event. In wet conditions, Mg spiked at SP4 and SP11 showing concentrations of $4250 \mu \mathrm{g} / \mathrm{L}$ and $4510 \mu \mathrm{g} / \mathrm{L}$ respectively - these were the highest recorded concentrations of $\mathrm{Mg}$ in water. The $\mathrm{Mg}$ concentrations for SP4 and SP11 were $3150 \mu \mathrm{g} / \mathrm{L}$ and $2960 \mu \mathrm{g} / \mathrm{L}$ respectively in dry conditions and were not significantly different from other points. SP3 had a high concentration of $\mathrm{Mg}$ in wet conditions, possibly due to the proximity of Twyford Lane. Mg concentrations generally decreased with distance from the fords.

Mn results ranged between $<5$ and $998 \mu \mathrm{g} / \mathrm{L}$ during dry conditions and $<5$ to $1010 \mu \mathrm{g} / \mathrm{L}$ in wet conditions (Figure 3). SP3 was an outlier in both, and recorded concentrations of 998 and $1010 \mu \mathrm{g} / \mathrm{L}$ respectively. Mn concentrations were slightly elevated after the precipitation event at SP4 and SP11, at 52 and $45 \mu \mathrm{g} / \mathrm{L}$ respectively when compared to $6 \mu \mathrm{g} / \mathrm{kg}$ at both positions during a dry period. Mn levels were relatively high at SP14 during both wet and dry conditions at $28 \mu \mathrm{g} / \mathrm{L}$ and $32 \mu \mathrm{g} / \mathrm{L}$ respectively.

\subsection{Sediment Chemistry}

Five control samples were taken from the underlying Ashdown Formation, the sole geology up- and down-stream of the study sites, at depths of between $0.30 \mathrm{~m}$ to $0.60 \mathrm{~m}$ and were tested for $\mathrm{As}, \mathrm{Cr}, \mathrm{Cu}, \mathrm{Pb}, \mathrm{Mg}, \mathrm{Mn}, \mathrm{Ni}$ and $\mathrm{Zn}$. The results are summarised and compared to the ford river crossing results (this included all results from $1 \mathrm{~m}$ upstream and $10 \mathrm{~m}$ downstream of each respective ford) in Figure 4. Without exception, it was found that 
elemental concentrations in sediments were above the average background level from sediments near the ford crossings. However, all elemental concentrations identified in the sediments were below varying human health criterion and estimated background chemistry (with reference to an Envirocheck Datasheet), shown in Table 1.

The impact that the fords and roads were having on contaminant loading into the main channel is illustrated in Figure5. Figure 5 shows an inverse association between the concentration of elements and distances of road, and also shows significant correlation between the concentration of metals and distances from the fords. Of the metals, $\mathrm{Zn}, \mathrm{Pb}$ and $\mathrm{Cr}$ have the most significant correlation.

The mean concentration of $\mathrm{Pb}$ was $16 \mathrm{mg} / \mathrm{kg} \pm 6.15(1 \sigma)$, reflecting moderate spatial homogeneity. No outliers were identified. Figure 5ai suggests that $\mathrm{Pb}$ was most closely associated with road proximity, given the $R^{2}$ value of 0.6 . Figure 5aii shows a significant relationship between downstream distance and $\mathrm{Pb}$ concentration. The spatial distribution map (Figure 6) suggested an influx of $\mathrm{Pb}$ at both ford crossings, particularly Ford 2. $\mathrm{Pb}$ concentrations at SP9 and SP12 were the highest recorded, when compared to background levels, in the major stream at $27 \mathrm{mg} / \mathrm{kg}$ and $24 \mathrm{mg} / \mathrm{kg}$ respectively. SP11 was slightly lower at $20 \mathrm{mg} / \mathrm{kg}$.

The mean value for $\mathrm{Cr}$ was $19 \mathrm{mg} / \mathrm{kg} \pm 12.35$, which suggests high spatial heterogeneity. No outliers were identified. $\mathrm{Cr}$ concentrations displayed the second strongest inverse relationship with distance from the road with $R^{2}=0.58$ (Figure 5bi), suggesting a significant relationship. There was a similar inverse relationship between $\mathrm{Cr}$ distance downstream from the fords, $\mathrm{R}^{2}=0.63$ (Figure $5 \mathrm{bii}$ ), the strongest for the metals considered here. At 
immediately upstream (SP2) and downstream (SP4) respectively. Similarly, at Birchgrove Lane Ford (Ford 2) concentrations of $33 \mathrm{mg} / \mathrm{kg}$ and $37 \mathrm{mg} / \mathrm{kg}$ were recorded at SP9 and SP11 respectively. The maximum $\mathrm{Cr}$ concentration, $41 \mathrm{mg} / \mathrm{kg}$, was recorded at $\mathrm{SP} 12 . \mathrm{Cr}$, in general, decreased downstream with increasing distance from the crossings. Upstream of both, $\mathrm{Cr}$ was recorded at $4.0 \mathrm{mg} / \mathrm{kg}$ (the lowest concentration) and at SP14, 100m downstream from Ford 2, Cr was noted at $5.7 \mathrm{mg} / \mathrm{kg}$. Spatial distribution maps (Figure 6) identified both fords as having increased $\mathrm{Cr}$ concentrations relative to background levels. Concentrations peaked at the crossings before they gradually decreased downstream with distance of the ford. Moderate concentrations of $\mathrm{Cr}$ were identified in the MS2.

The mean concentration of $\mathrm{Zn}$ was $94 \mathrm{mg} / \mathrm{kg} \pm 38$, indicating high spatial heterogeneity, although no outliers were identified. Figure $5 \mathrm{ci}$ shows an $\mathrm{R}^{2}$ value of 0.53 indicating a moderate relationship between road distance and $\mathrm{Zn}$ concentrations. Spatial analysis (Figure 6) highlights elevated Zn, when compared to background levels, downstream of both ford crossings, with a minor increase also being located at SP8. MS1 provided a large influx of Zn with concentrations of $142 \mathrm{mg} / \mathrm{kg}$ and $134 \mathrm{mg} / \mathrm{kg}$ respectively at SP16 and SP3. Concentrations at SP14 were higher than expected at $96 \mathrm{mg} / \mathrm{kg}$.

$\mathrm{Mn}, \mathrm{Mg}, \mathrm{As}, \mathrm{Ni}$ and $\mathrm{Cu}$ all had low $\mathrm{R}^{2}$ values both for road distance and for ford distance. However, all had heterogeneous, and mostly higher than background concentrations, nearer to the road or ford crossing, which decreased abruptly with distance.

$\mathrm{Cu}$, As and $\mathrm{Ni}$ all had no discernible relationship relationship with ford distance, their high standard deviations indicated a high spatial heterogeneity with no correlation to the fords. $\mathrm{Cu}$ and $\mathrm{Ni}$ did not show evidence of loading at the fords. The highest $\mathrm{Cu}$ concentration (12 $\mathrm{mg} / \mathrm{kg}$ ) was recorded at SP12. 
A consistent feature of the spatial distribution diagrams (Figure 6) was the influx of metals from MS1 flowing from Twyford Lane (SP16 and SP3) and joining the mainstream course immediately before Ford 1 . However, both ford crossings and their road surfaces were evidently a source of $\mathrm{Zn}, \mathrm{Pb}, \mathrm{Cr}$ and, to a lesser extent, $\mathrm{Mg}$ to the river system.

\subsection{Macroinvertebrate samples}

261

A strong negative correlation between BMWP score and distance from the road was identified by an $\mathrm{R}^{2}$ value of 0.56 (Figure $7 \mathrm{a}$ ), and Figure $7 \mathrm{~b}$ identifies a significant correlation between increasing distance from the ford crossing and increased BMWP score. BMWP results downstream of the fords were generally lower than those upstream (Figure 7c). BMWP scores of 110 and 135 were recorded $10 \mathrm{~m}$ and $50 \mathrm{~m}$ upstream of Twyford Lane Ford (Ford 1) respectively, whereas downstream of the ford, scores of 55 and 65 were recorded at the same distances. In general, with increased distance downstream from Ford 2, BMWP scores increased. An exception is the site $10 \mathrm{~m}$ downstream from Ford 2 which had a lower BMWP score (21) than $0.5 \mathrm{~m}$ and $5 \mathrm{~m}$ downstream (36 and 38 respectively). These lower BMWP scores correlate with increased concentrations of $\mathrm{Cr}, \mathrm{Pb}$ and $\mathrm{Zn}$.

Because of the limitations of BMWP scores, species/family analysis was undertaken. Figure8 highlights presence on the basis of the following scale created by the author:

A - Abundant: The presence of such species is numerous in the sampling tray and represent a vast, often dominant, proportion of the total invertebrates' c.20+ individuals. the sampling tray c.10-20 individuals. 
O - Occasional: A species which is present relatively small quantities usually $3-9$ individuals.

R-Rare: A species where only 1 or 2 individuals are identified.

Abs - Absent: The species was not identified at the sampling point.

Figure 8 shows that Ephemeroptera, is mostly rare in Ford 1 and absent in Ford 2, becoming abundant with distance from the ford. Plecoptera expresses a similar frequency, however, it is not recorded in abundance anywhere in the stream. Trichoptera lessens in abundance immediately downstream of both fords but is occasional and frequent immediately upstream in Ford 1 and Ford 2 respectively.

Pearson's Coefficient was used to determine the relationship between various metals and BMWP score, the results are summarised in Table S11- SI. Table S11 - SI identifies that Zn, $\mathrm{Pb}$ and $\mathrm{Cr}$ have Pearson's Coefficients with BMWP score of $-0.77,-0.75$ and -0.71 respectively. From this, it is determined that the concentrations of these metals have significant negative impacts on BMWP score. Mn and Mg had Pearson's Coefficient scores of -0.52 and -0.37 respectively, showing a quite strong negative correlation. Elements $\mathrm{As}, \mathrm{Cu}$ and $\mathrm{Ni}$ had correlations of $-0.28,-0.18$ and -0.02 respectively showing weak to negligible negative correlations.

Figure 9 indicates that $\mathrm{Cr}, \mathrm{Pb}$ and $\mathrm{Zn}$ have an influence on species composition. $\mathrm{Mn}, \mathrm{Mg}$ have some influence on species composition whereas $\mathrm{As}, \mathrm{Cu}$ and $\mathrm{Ni}$ do not show discernible influence. 
Results of DO (Table S12 - SI and Figure S2 - SI) were consistent at all sampling points, ranging between 7 and $9 \mathrm{mg} / \mathrm{l}$, with the exception of SP3 which had a DO level of c. $3 \mathrm{mg} / \mathrm{L}$. Additionally, no other evidence of depleted DO levels, such as an algal growth, were observed. TDS results, converted using an electrical conductivity meter, were in the range of 158 and $203 \mathrm{mg} / \mathrm{L}$, this was commensurate with the expected TDS level for hard water.

On average, $\mathrm{pH}$ was slightly higher during dry conditions (Table S13 - SI and Figure S3 - SI). The majority of results fell between the optimum range for freshwater of $\mathrm{pH} 6.5-\mathrm{pH} 7.5$ (Namiesnik and Szefer, 2010).

Flow was recorded at all sampling locations on two separate occasions (after prolonged dry and wet periods) and was broadly in the range of $0.023-0.068 \mathrm{~m} / \mathrm{s}$ at the main channel (Figure S4 -SI and S5 - SI).

Particle size distribution (PSD) and particulate organic carbon (converted to soil organic matter-SOM) tests were undertaken at each location where sediment samples were taken. No discernible relationship between fine particles, SOM and the three most prevalent metal concentrations ( $\mathrm{Zn}, \mathrm{Pb} \& \mathrm{Cr}$ ) was obtained (Figure 10 and Table S14 - SI). The results of correlation coefficients to discern relationships between particle size, SOM and element concentrations (Table S15 - SI) highlights very weak to weak correlations between metal concentrations and soil variables in most instances. Exceptions were $\mathrm{Cr}$ and $\mathrm{Mg}$ which both had a moderate negative correlation with percentage of SOM. Additionally, $\mathrm{As}, \mathrm{Pb}$ and $\mathrm{Cu}$ had moderate positive correlations with percentage of fine sediment particles. 


\section{Discussion}

\subsection{Comparisons with Guideline Criteria}

323 Results from the sediment samples were compared to several criteria (Table 1 ): Estimated Background Value (from Landmark Dataset), SGVs and C4SL or SSAC depending on which gave the lower value. No metal concentration exceedances, deemed hazardous to human health, were identified. However, concentrations considered detrimental to human health do not necessarily pertain to macroinvertebrates. In most instances, macroinvertebrate communities are more sensitive. Cadmus et al. (2020) identified that the sensitivity of aquatic invertebrates was size dependent, therefore, it is assumed that human health guidelines are further removed for the sensitivity thresholds of aquatic invertebrates at various life cycle stages. As such, the comparisons made in Table 1 are used solely as an indicator.

The results of the chemical analysis for determinands known to be phytotoxic are summarised in Table 2, together with the respective adopted Generic Assessment Criteria (GAC) for plant growth. The compliance criteria set out in BS3882:2015 are $\mathrm{pH}$ dependent and thus the GAC used relate to the $\mathrm{pH}$ range measured on samples recovered from the site. No exceedances in determinand concentrations that are considered phytotoxic were identified.

Ranges of elemental concentrations were compared to ranges taken from other rivers around the world as identified in Pandey et al's. (2019) study Table S16 - SI. In general, the metal concentrations were lower in the present study than those of Pandey et al's study, 
however, it should be noted that the present study is focused on a tributary in a rural setting rather than a main river channel that passes urban areas.

5.2 Impact of ford river crossings on heavy metals and macroinvertebrate composition

The elemental concentrations observed above background levels are likely to be attributable to the ford crossing and nearby road network, and therefore, may influence ecological composition. Road surface runoff has often been identified as a key source of metal loading into waterways (Haus et al., 2006; Stucker, et al., 2016 and Sebastiao et al., 2017). In addition, fords are generally low-elevation parts of the roadsand accumulate pollution from upgradient. It is also apparent that water quality of the channels downstream of the fords has been affected by vehicle-derived contaminants, the impact of which seems to be exacerbated by precipitation events which wash road dust into the waterways.

\subsubsection{Water Chemistry}

Influxes of heavy metal contamination during dry conditions were not encountered, however, wet conditions did experience influxes of $\mathrm{Zn}, \mathrm{Mg}$ and $\mathrm{Mn}$.

The concentrations of $\mathrm{Zn}$ in water were generally below detection $(5 \mu \mathrm{g} / \mathrm{L})$, however, in proximity to the ford crossings vehicular wash-off apparently contributes to overall $\mathrm{Zn}$ concentration. Of equal or more significance is the greater concentration of $\mathrm{Zn}$ and $\mathrm{Mg}$ recorded at the main channel during a precipitation event following a prolonged dry period, recorded at $22 \mu \mathrm{g} / \mathrm{L}$ and $38 \mu \mathrm{g} / \mathrm{L} \mathrm{Zn}$, and $4250 \mu \mathrm{g} / \mathrm{L}$ and $4510 \mu \mathrm{g} / \mathrm{L} \mathrm{Mg}$ at sampling positions 
located immediately downstream of Ford 1 and Ford 2 respectively. Although such concentrations are below their respective threshold values, they do indicate localised loading when compared to background concentrations. This pattern was not observed for Mn. Sample point SP3, at Minor Stream 1 (MS1), recorded concentrations of Mn at $998 \mu \mathrm{g} / \mathrm{L}$ and $1010 \mu \mathrm{g} / \mathrm{L}$ in dry and wet respectively, far higher than the next highest concentration of and S18 -SI) did not identify any industrial activity, either contemporary or historical, near MS1 other than farms. Although $\mathrm{Mn}$ is ubiquitous in the environment $\left(\mathrm{O}^{\prime} \mathrm{Neal}\right.$ and Zheng, 2015), occurring in soil concentrations of $40-900 \mathrm{mg} / \mathrm{kg}$ (O'Neill, 1998), the spike in Mn could have come from the use of agricultural fungicides in the adjacent agrarian land. Alternatively, elevated $\mathrm{Mn}$ concentrations are a likely product of low DO levels $(3 \mathrm{mg} / \mathrm{L})$ leading to a reducing environment allowing $\mathrm{Mn}$ to be liberated from the weathering of local geology thus dissolve more readily. By comparison, Mn concentrations fall to $13 \mu \mathrm{g} / \mathrm{L}$ (dry) and $26 \mu \mathrm{g} / \mathrm{L}$ (wet) at SP2, which had a DO of $7 \mathrm{mg} / \mathrm{L}$ and is located $5 \mathrm{~m}$ downstream of SP3 in the confluence at MS1 and the main channel. The main channel has a discharge of 0.068 $\mathrm{m}^{3} / \mathrm{s}$ at SP2 which dilutes the water from MS1 (discharge of $0.0032 \mathrm{~m}^{3} / \mathrm{s}$ ) resulting in lower Mn concentrations and higher DO levels.

$\mathrm{pH}$ levels of the water were generally within the optimum range for freshwater. The expected slight fall of $\mathrm{pH}$ after rainfall was most pronounced around Ford 2, probably due to less vegetation cover to intercept the rainfall which, with its lower $\mathrm{pH}$ (avg. $\mathrm{pH}$ 5.6), would mix with river water to slightly reduce the $\mathrm{pH}$. The lowest $\mathrm{pH}$ recorded was 6.2 (see Table S13 in SI). Gerhardt (1992) identified ion regulation to be disturbed by $\mathrm{H}^{+}$and $\mathrm{Al}^{3+}$ ions which are elevated in acidified waters, a subject for further study. Further testing may identify if 
prolonged rainfall acidifies the stream waters, therefore altering the chemical interactions, over a seasonal time scale.

Elemental concentrations do not exceed thresholds from the European Water Framework Directive (WFD), but do indicate (see t-test Table S19 - SI) that first flush run-off is an important contributor to metal loading into waterways, as discussed by Haus et al., (2006). Concentrations of $\mathrm{Mg}$ and $\mathrm{Zn}$ experience exponential fall toward the mean value with increased distance from each ford, another indicator of the surface run-off being the source. Paired two sample t-tests for concentrations of $\mathrm{Mg}, \mathrm{Mn}$ and $\mathrm{Zn}$, comparing wet and dry conditions with a $95 \%$ confidence level, suggest that precipitation events do indeed lead to influxes of $\mathrm{Mg}$ and $\mathrm{Zn}$. The result for $\mathrm{Mn}$ is outside the confidence interval, likely influenced by sources from Minor Stream 1.

\subsubsection{Sediment Chemistry}

Numerous studies, including Sebastiao et al. (2017) identify surface runoff as a major source of metal contamination. Metal concentrations at their study site, Righters Mill Road Ford (RMRF) in Philadelphia, USA were significantly higher than those at Twyford Lane (Ford 1) and Birchgrove Road (Ford 2) despite having similar traffic volumes. However, both studies have demonstrated significant correlations between sediment metal concentrations and proximity to ford crossing and roads. Land use setting is the most likely explanation for the differences in concentrations. RMRF is located in a suburban area with a dense road network, as opposed to the rural setting of Twyford Lane and Birchgrove Road. This corresponds with the observations of Stucker et al. (2016), who identified significantly increased concentrations of $\mathrm{Cr}, \mathrm{Pb}$ and $\mathrm{Mo}$ in waterways near to roads and found land use type to be a main driver of dissolved metal concentrations. It seems sensible that higher 
concentrations of sediment metals are found in an urban setting. However, the recognition

that road-derived elements are heavily influenced by particle size distribution, perhaps even more so in terms of their recalcitrance, enabling them to reside for prolonged periods within sediments, and should not be underplayed Wang et al. (2019).

$\mathrm{Pb}, \mathrm{Cr}$ and $\mathrm{Zn}$ all show a marked increase in sediment concentration around both ford crossings, particularly at those closest to the downstream sampling point. The spatial distribution diagrams (Figure 6) identify the crossings as accumulation points for these metals. Generally, concentrations of metals increase at Ford 1, then decrease with distance downstream, only to spike again at Ford 2 subsequently regressing to the mean value, as predicted in the conceptual model (Figure 2). It therefore seems probable that the ford crossings are indeed sources of increased metal loading, particularly of $\mathrm{Pb}, \mathrm{Cr}$ and $\mathrm{Zn}$. Attenuation distance graphs (Figure 11) estimates that $\mathrm{Zn}$ returns to background range by ca. $450 \mathrm{~m}$, but the critical distances for $\mathrm{Cr}$ and $\mathrm{Pb}$ are significantly shorter at ca. 106 and ca. 180 m respectively.

Concentrations of some elements recorded at SP12 (10 m downstream from Ford 2) were higher than at SP11 (immediately downstream of Ford 2 where slightly lower concentrations would be expected). For example, $\mathrm{Pb}$ and $\mathrm{Cr}$ at SP11 are $20 \mathrm{mg} / \mathrm{kg}$ and $37 \mathrm{mg} / \mathrm{kg}$ respectively, whereas at SP12, concentrations were $24 \mathrm{mg} / \mathrm{kg}$ and $41 \mathrm{mg} / \mathrm{kg}$ respectively. The concentrations then decline downstream at SP13 and SP14 (Figures 10). SP11 predominantly comprised a hard-standing bed (concrete) with a faster fast flow $(0.046 \mathrm{~m} / \mathrm{s}$ compared to $0.031 \mathrm{~m} / \mathrm{s}$ at SP12) which is unfavourable for the deposition of fine-grained material (Hugget 2007). Lower metal concentrations at SP11 are therefore possibly the result of a lack of clay and SOM which would impede adsorption (Yao et al., 2015). PSD 
measurements (Figure 10 and Table S14 - SI) show that SP11 had 1.3\% fines while SP12,

434 located $10 \mathrm{~m}$ downstream of Ford 2, had 19.6\% fines. Furthermore, this also corresponds 435 with the findings of Wang et al. (2019) who found preferential accumulation of lead and zinc in finer road-deposited sediments, however, their study was undertaken to a finer resolution (<38.5 $\mu \mathrm{m}$ for Wang et al., $63 \mu \mathrm{m}$ for this study).

Differences in SOM were not so pronounced (see Figure 10). SP14 (110 m downstream of

Ford 2) has shown slight peaks in concentrations of $\mathrm{As}, \mathrm{Cr}, \mathrm{Cu}, \mathrm{Mg}, \mathrm{Ni}$ and $\mathrm{Zn}$, which may also be related to its relatively high clay and SOM contents. However, it should be noted that organic material can serve as a source of elemental contamination through the manure from adjacent sheep pasture (Robinson et al., 2000).

Pearson's coefficients (Table S20 - SI) confirms elevated concentrations of $\mathrm{Pb}, \mathrm{Zn}$ and $\mathrm{Cr}$ to be linked with proximity with ford crossings (i.e. concentrations decrease with increased distance). Mn and Mg were moderately associated with fords. SP11 (closest downstream of $\mathrm{mg} / \mathrm{kg}$ ), though of no concern with regards to toxicity. SP11 is located near the drainage duct running alongside Birchgrove Road, from which sediment samples recorded relatively high Mg concentrations $(2940 \mathrm{mg} / \mathrm{kg}$ ), suggesting that the drainage duct is a secondary source of $\mathrm{Mg}$, but it is unknown where from.

\subsubsection{Pollution Sources}

The elements identified at increased concentration, in comparison to background levels, have been found to be associated with vehicles in previous studies. Although $\mathrm{Pb}$ is no longer 
found as an additive in fuels in the UK, it has been found adsorbed onto to roadside soils due to its long persistence (Loganathan et al. 2013). This would act as a contributing factor to increased $\mathrm{Pb}$ concentrations. Sutherland and Tolosa (2001) found a linear decrease in $\mathrm{Zn}$ and $\mathrm{Pb}$ concentrations when comparing concentrations of elements with road distance, corresponding with decrease of the same elements in this study. This indicates that vehicular pollution is the likely source of two of the metals most closely associated with arresting ecological succession in this study, therefore, impeded dispersal and colonisation.

Although all elements have been associated with vehicles in previous studies, it is likely that the elements incorporated within the river sediments are derived from a variety of anthropogenic and natural sources. However, with reference to Wang et al (2019), road deposited sediments accumulate on road surfaces during dry periods and present differences in dissolvability depending on their residence sites and bonding. As a result, Wang et al (2019) found that almost half of $\mathrm{Ni}$ and $7 \% \mathrm{Zn}$ found within road deposited sediments had been transported in the dissolved form via storm water. This finding correlates with the concentrations of dissolved $\mathrm{Zn}$ found in proximity to the crossings and also with the low concentrations of $\mathrm{Ni}$ found within the river sediments.

471 Road-derived sediments are also a factor of the roadway material. Loganathan et al. (2013) suggested that mineral aggregates, comprising different rock materials, have differing concentrations of metals. The wearing down of these aggregates have the propensity, albeit 474 at different levels, to contribute metalliferous materials into the road dusts as asphalt is worn down. Study into the elemental composition of the road material around the two fords may identify the significance of such variability. 
478 Charlesworth et al. (2003) identified the elements with the highest potential for 479 bioavailability in their study in two urban rivers in the UK to be $\mathrm{Cd}>\mathrm{Zn}>\mathrm{Cu}>\mathrm{Pb}>\mathrm{Ni}$. Their 480 study found that only a small fraction of the heavy metals was bound to readily exchangeable sites. The Zn identified in Charlesworth et al's. (2003) study was found to be associated with carbonates, hence its increased bioavailability. However, in the current study Zn was not found to correlate with SOM (using TOC as a proxy) but was associated with a decrease in biodiversity. Clearly, more work is required to identify speciation of elements found to negatively impact the ecology.

Spot sampling and analysis of water and sediments gives only a snapshot of the metals in the system. Biomonitoring allows longer-term estimation of water quality due to the responses of sensitive invertebrates. Although zinc is an essential element, the WHO (2001) identifies concentrations of $20-50 \mu \mathrm{g} / \mathrm{l}$ to have chronic effects on cladocerans and concentrations of $50-100 \mu \mathrm{g} / \mathrm{l}$ to have chronic to acute effects, depending on water hardness, on freshwater invertebrates. Additionally, several studies (Armatage, 1980; Malmqvist \& Hoffsten., 1999; \& Beasley \& Kneale., 2002) have identified Zn as the element having the most pronounced negative effect on taxonomic diversity, further backed up by Clements (1994) who demonstrated a distinct decline in biodiversity associated with increased levels of $\mathrm{Zn}$. have a direct negative impact on biodiversity. $\mathrm{Zn}$ followed by $\mathrm{Pb}$ and $\mathrm{Cr}$ were shown to have the strongest negative correlation. Hexavalent $\mathrm{Cr}\left(\mathrm{Cr}^{6+}\right)$, the more mobile, more bioavailable and more toxic form, was below detection limit $(0.8 \mathrm{mg} / \mathrm{kg}$ ) in all samples (possibly due to reduction by SOM), thus the $\mathrm{Cr}$ detected was trivalent. The impact of $\mathrm{Zn}$ in reducing the 
501

502

503

504

505

506

507

508

509

510

511

512

514

515

516

517

BMWP score accords well with the results of Clements et al. (2013). Zn has long been identified as one of the most mobile metals (Langston \& Bebianno, 1998), forming inorganic and organic complexes - many of which are soluble. $\mathrm{Zn}$ ions have been found to lead to hypocalcaemia in fish by competing with Ca ions (Hogstrand et al., 1993), which could lead to localised habitat fragmentation.

Ni had almost no impact whilst $\mathrm{Cu}$ and $\mathrm{As}$ had a negligible impact. $\mathrm{Mn}$ and $\mathrm{Mg}$ were identified as having a moderate impact on biodiversity, but both have low toxicity. As such, the moderate Pearson's Coefficient score associated with $\mathrm{Mn}$ and $\mathrm{Mg}$ and their respective BMWP scores may be more of a product of their higher concentrations towards the ford crossings and the relationships with the other metals.

The increased concentration of some metals and decrease in BMWP score do appear to be intrinsically linked. Other variables such as discharge, EC, river bedload and shade cover do not show any significant relationship. The dissolved oxygen tests did not show evidence of organic pollution. Flow and bedload did not appear to have any observable impact on biodiversity in the absence of elevated heavy metals. An invertebrate species that colonises appropriate areas, e.g. Philopotamidae - a taxonomic group known to inhabit faster flowing stretches - was largely absent from areas of the main channel with a low velocity, even when BMWP scores were high. Philopotamidae however, was found in higher velocity areas suggesting that colonisation had been enabled and that velocity does impact composition of species but not overall biodiversity, as other species will take their place.

Although the BMWP score is a good indicator of habitat quality, the score does not give indications of species with high tolerances and, therefore, has the potential to give misleading results. As such, the identification of individual species with known tolerances is 

occurrences of Ephemeroptera at sampling points near the fords and roads. Such absences and rarities in Ephemeroptera are correlated with areas where higher concentrations of $\mathrm{Zn}$,

$\mathrm{Pb}$ and $\mathrm{Cr}$ have been recorded, suggesting that these metals are, at least partly, a factor of the scarcity of Ephemeroptera. Trichoptera are considered more resistant to contaminants and, although not particularly abundant at any location, were recorded more frequently in proximity to the fords, filling the niche left from the absent Ephemeroptera. Plecoptera, observed to have variable sensitivity, were found to be absent in locations closest to the fords and to have occasional abundance in locations closest to roadsides. Conversely, Plecoptera were noted to be abundant or frequent at locations with increased distances from the fords. The biomonitoring results therefore suggest that the ford crossings are having a negative impact on biodiversity as a result of metal loading.

\subsection{Implications for river ecology and environmental protection}

538 A conceptual contamination model and interaction of various environmental components is presented in Figure 13 indicating the complex nature of the potential for ongoing elemental

540 loading. In conjunction with Sebastiao et al's. 2017 study (Table S22 - SI), there is significant evidence of elemental loading in river waters where they meet ford crossings which are

542 likely derived from vehicle wash-off and road surface runoff. What is not clear however, is the amount of airborne particulate matter that falls out into the freshwater system. Sahu and Elumalai (2017) identified a threefold increase in concentrations of $\mathrm{Zn}$ and $\mathrm{Cu}$ particulates on roadsides adjacent to traffic calming devices. It would seem sensible to assume that ford crossings act similarly to traffic calming devices as vehicles slow down on 
approach. This could serve to exacerbate the metal loading from air-deposited particulate matter, a subject for further study. Eight no. dustscan discs were placed around the study site at locations SP1, SP3, SP4, SP7, SP9 and SP14. However, the results from this aspect were inconclusive due to coverage of leaf litter and the loss of three of the discs, therefore, the air monitoring element was omitted from the study

The Government of Western Australian Department for Water and Environmental Regulation - Water Quality Protection Note (WQPN) identifies the need for careful selection of crossing points over freshwaters. Appendix D of WQPN indicates a $75 \mathrm{~m}$ vegetated buffer zone for bridge crossings to minimise contamination. However, no such protection measures have been identified for ford crossings. The results from the chemical and ecological analysis at Birchgrove and Twyford Lanes should be helpful when selecting new crossing points over sensitive waters, especially in the light of increased infrastructural pressures. An estimated critical distance of $150 \mathrm{~m}$ from the crossing is suggested to allow for attenuation of metal concentrations to background levels. However, Figure 11 indicates that this is dependent on the element concerned, for example the critical distance (the distance for concentrations to attenuate toward backgrounds levels) for $\mathrm{Zn}$ was estimated to be 450 $\mathrm{m}$ as opposed to ca. $115 \mathrm{~m}$ for $\mathrm{Cr}$. Pb fell between the two, with an estimated critical distance of $180 \mathrm{~m}$. Further study is also required to elucidate seasonal changes, i.e. changes in winter include loss of vegetation cover reducing trapping of airborne particulates, temperature changes and discharge in water during winter months may increase EC, alter $\mathrm{pH}$ and decrease deposition, and finally, the addition of $\mathrm{NaCl}$ onto road surfaces in winter which enters the water system will affect sorption and the reactional kinetics. Consideration of sediment composition is also important. As indicated in Figures 10 and 12, bedload sedimentology can, at first inspection, suggest misleading attenuation distances. Figure 12 
571 shows lower concentrations of $\mathrm{Cr}$ and $\mathrm{Pb}$ in SP11, the sample point immediately

572 downstream of Ford 2, than those of SP2 - 10m downstream of Ford 2. An explanation of

573 the peak at SP12 is that the fine materials or the clays in SP12 adsorb the metals in question

574 more effectively than the hardstanding bed at SP11. Therefore, in future designs, although

575 hardstanding concrete may promote faster flow and lack of absorption, such designs may

576 skew attenuation data as contamination is mobilised only to be stored further downstream

577 in more favourable conditions.

578 Since vehicle manufacturing processes respond to the inevitable developments of new

579 technologies, so might the elemental contaminants introduced into the environment. As

580 seen with $\mathrm{Pb}$, some contaminants have a long residence time and may persist long into the

581 future.

582 Although the study site is along relatively quiet stretches of rural roadways, it would be expected that for more heavily trafficked areas the results would be magnified such as identified in Sansalone et al. (1996), Davis et al. (2001), Loganathan et al. (2013) and Sebbastiao et al. (2017). Therefore, the impact to ecology would be more significant. The results highlight the importance of placing mitigation measures in areas where road-derived sediments migrate into waterways. With reference to Wang et al. (2019), such strategies should focus on very fine particles within road sediments and suspended in storm water, as these are associated with higher accumulations of heavy metals, as indicated in discussed earlier. Additionally, changes in $\mathrm{Eh}$ and $\mathrm{pH}$ associated with agricultural activities, sewage discharges and rain, could release heavy metals, making them more bioavailable. Further investigation into the speciation of identified elements would be required to elucidate this. 
more and better-quality roads, thought should be given to such strategies prior to any road construction.

The importance of understanding habitat fragmentation will increase, since mounting pressure on land use and the expected rise in vehicular traffic will continue to put strain on local environments. Although contamination into a river system via a road crossing (be it a ford or bridge) may only be localised, the impact is potentially catastrophic as "dead zones" may be created impeding important migratory routes. Additionally, habitat fragmentation will inevitably cause increased intra- and inter-species competition and alterations in trophic interactions (Wilson et al, 2015). As such, understanding the chemical and biological dynamics of river crossings will help planners give further thoughts to placement and mitigation of such crossings, particularly in sensitive areas.

\subsection{CONCLUSIONS}

- Heavy metals $\mathrm{Pb}, \mathrm{Cr}$ and $\mathrm{Zn}$ in sediments, and only $\mathrm{Zn}$ in water, show a marked increase in concentration at the closest downstream side of ford crossings. The concentrations of metals subsequently decrease with distance downstream, only to spike again at the next ford.

- Attenuation distances vary. For instance, in this study, Zn returns to background range by ca. $450 \mathrm{~m}$, but the critical distances for $\mathrm{Cr}$ and $\mathrm{Pb}$ are significantly shorter at ca. 106 and ca. $180 \mathrm{~m}$ respectively.

- As a result of the increased heavy metal loading, biodiversity and the presence of sensitive taxa was significantly reduced at positions located near ford crossings.

- No metal concentration in this study exceeded appropriate guidance values for human health. 
617

618

619

620

621

622

623

624

625

626

627

628

629

630

631

632

633

634

635

636

637

638

639

640

641

642

- The results of chemical and ecological analysis should be considered during selection and design of new crossings over sensitive waters, especially in the light of increased infrastructural pressures.

(1)

2

\section{Acknowledgements}

We are grateful for the detailed comments of two reviewers, which helped improve the manuscript.

We would also like to thank the following: Daniela Green, Chris Colyer, Patricia Colyer, Matthew

Green, David Emery, Luke Stock, Mark Wild, Tony Rigg, Andy Jones, and colleagues at The University of Portsmouth for their assistance with sampling, species identification and general support.

8

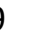




\subsection{References}

653

654

Adamiec, E., Jarosz-Krzeminska, E., Wieszała, R., (2016). Heavy Metals from Non-Exhaust 655 Assessment. 188, pp.1-11.

657

658

Adur

$\& \quad$ Ouse

Partnership.

(2018).

Ouse

Catchment. Available:

659 http://www.adurandousecatchment.org.uk/index.php/sub-catchments/river-ouse/river-

660 ouse-description. Last Accessed: 12th June 2018.

661

662

Amiard-Triquet, C., Rainbow, P.S., Romeo, M., (2011). Tolerance to Environmental 663 Contaminants. CRC Press, Boca Raton.

664

665

Armitage, P.D., 1980. The effects of mine drainage and organic enrichment in benthos in the 666 river Nent system, northern Pennines. Hydrobiologia, 74, pp.119-128.

667 
668

669

670

671

672

673

674

675

676

677

678

679

680

681

682

683

684

685

686

687

688

689

690

691

Beasley, G. and Kneale,, P.E., (2003). Investigating the Influence of Heavy Metals on

Macroinvertebrate Assemblages using Partial Canonical Correspondence Analysis (pCCA).

Hydrology and Earth System Sciences. 7 (2). pp. 221 - 233.

Costas, N. Pardo, L. Méndez-Fernández, M.Martínez-Madrid and P.Rodríguez (2018) Sensitivity of Macroinvertebrate Indicator Taxa to Metal Gradients in Mining Areas in Northern Spain. Ecological Indicators. Vol 93. Pp.207 - 2018.

Cadmus, P. Kotalik, C.J. Jefferson, A. L. Wheeler, S.H. McMahon, A.E and Clements, W. H. (2020) Size-Dependent Sensitivity of Aquatic Insects to Metals. Environmental Science and Technology. 54(2). Pp.955-964.

Carter, J and Resh, V, H. (2001). After Site Selection and Before Data Analysis: Sampling, Sorting and Laboratory Procedures Used in Stream Bethnic MAcroinvertibrate Monitoring Programs by USA State Agencies. Journal of Limnology Vol. 60. pp. 1 - 6

Charlesworth, S., Everett, M., McCarthy, R., OrdÓňez, A. and de Miguel, E, (2003).A Comparatice Study of Heavy Metal Concentration and Distribution in Deposited Street Dusts ina Large and Small Urban Area: Birmingham and Coventry, West Midlands, UK. Environmental International. Vol. 29, pp.563-573.

Clements, W.H. (1994). Benthic Invertebrate Community Response to Heavy Metals in the Upper Arkanses River Basin, Colorado. Journal of the North American Bentholohical Society. Vol 13 (1). pp.30-44 
693 Clements, W. \& Cadmus, P. \& Brinkman, S. (2013). Responses of Aquatic Insects to Cu and 694 Zn in Stream Microcosms: Understanding Differences Between Single Species Tests and 695 Field Responses. Environmental science \& technology. Vol. 47 (10) pp.7506-7513.

696

697 Davis, A.P., Shokouhian, M., Ni, S., (2001). Loading Estimates of Lead, Copper, Cadmium and 698 Zinc in Urban Runoff from Specific Sources. Chemosphere. 4, pp.997-1009

699

700

Debinski, D.M. \& Holt, R.D., (2000). A Survey and Overview of Habitat Fragmentation 701

Experiments. Natural History Museum and Centre for Biodiversity Research. USA

702

703

DEFRA, 2013. Development of Category 4 Screening Levels for assessment of land affected 704 by contamination - SP1010, London: DEFRA.

705

706

Department of the Environment (1996). Industry Profile: Road vehicle fuelling, service and

707 repair - garages and filling stations. DOE.

708

Department of the Environment (1996). Industry Profile: Transport Haulage Centres. DOE.

710

711

Department of Water - Government of Western Australia. (2006) Water Quality Protection

712

Note (WQPN) - Roads Near Sensitive Water Resources.

713

714

DfT, (2016). Road Lengths in Great Britain 2015, London: Department for Transport. 
Edina Digimap (2018). Colour Raster: Sussex 1:50,000 [PDF] OS Roam Series. Retrieved from http://digimap.edina.ac.uk/roam/os

Geology of Britain Viewer. (2018). British Geological Survey. Available: http://mapapps.bgs.ac.uk/geologyofbritain/home.html?. Last Accessed: $8^{\text {th }}$ March 2018.

Gerhardt, A. (1993). Review of Impact of Heavy Metals on Stream Invertebrates with Special Emphasis on Acid Conditions. Water, Air and Soil Pollution. Vol. 66, pp. 289-314.

Haus, N. Zimmermann, S. Wiegand, J. Sures, B. (2006). Occurrence of Platinum and Additional Traffic Related Heavy Metals in Sediments and Biota. Chemosphere Vol. 66 pp.619-629.

Henderson, P.A. 2005. Practical Methods in Ecology. Blackwell publishing. UK. Hogstrand, C., Wilson, R.W., Polgard, D. and Wood, C.M. (1994) Effects of Zinc on the Kinetics of Branchial Calcium Uptake of Freshwater Rainbow Trout During Adaption to Waterborne Zinc. Journal of Experimental Biology. 186. pp.55-73.

Hugget, R.J., (2007). Fundamentals of Geomorphology. $2^{\text {nd }}$ Edition. Routledge. London.

Jonsson, A., Lindstrom, M., Bergback, B., (2002). Phasing out cadmium and lead emissions and sediment loads in an urban area. Science in the Total Environment, 292, pp.91-100. 
Kang, X. Somg, J. Yuan, H. Duan, Li, X. Li, N. Liang, X and Qu, B. (2017). Speciation of Heavy Metals in Different Grain Sizes of JiaozhouBay Sediments: Bioavailability, Ecological Rsk Assessment and Source Analysis on a Centennial Timescale. Ecotoxicology\& Environmental Safety. 143 pp.296-306.

Knappett, J.A. \& Craig, R.F. (2012). Craig's Soil Mechanics. $4^{\text {th }}$ ed. Spon Press. Oxen, UK.

Langston, W.J. and Bebianno, M.J. (1998). Metal Metabolism in Aquatic Environments. Chapman and Hall. London.

Loganathan, P. Vigneswaran, S. and Kandasamy, J. (2013). Road-Deposited Sediment Pollutants: A Critical Review of their Characteristics, Source Apportionment, and Management. Critical Reviews in Environmental Science and Technology. Vol. 43. pp. 13151348.

Luoma SN, Rainbow PS . (2010). Linking New Science Frontiers in Metal Ecotoxicology to Better Risk Management: Lateral Thinking. Essential Reviews in Experimental Biology. 2 (1). pp. $1-28$.

Malmqvist, B. and Hoffsten, P., 1999. Influence of drainage from old mine deposits on benthic macroinvertebrate communities in central Swedish streams. Water Resources., 33, pp.2415-2423.

Mason, C. 2002. Biology of Freshwater Pollution 4th Ed. Pearson Prentice Hall. China. 
764 Naiman, R.J., Decamps, H. and McClain, M.E. (2005). Riparia: Ecology, Conservation and Management of Streamside Communities. Elsevier. London.

766

767

Namiesnik, J. and Szefer. P. (2010). Analytical Measurements in Aquatic Environments. CRC.

768 London.

769

770

O'Neal, S, L. and Zheng,W. (2015). Manganese Toxicity Upon Overexposure: A Decade in 771

Review. Current Environmental Health Report. Vole 2 (3). pp. 315 - 328.

772

773 O’Neill, P. (1998). Environmental Chemistry. $3^{\text {rd }}$ Edition. Blackie Academic and Professional.

774 London.

775

776

Pandey, L.K., Park, J. Son, D.H., Kim, W., Islam, M.S, Choi, S., Lee, H. and Hand, T. Assessment

of Metal Contamination in Water and Sediments from Major Rivers in South Korea from

2008 to 2015. Science of the Total Environment. Vol 651. (1). pp.323-333.

779

780

Primack, R.B. (2006) Essentials of Conservation Biology. (4th ed.), Sunderland, Sinuauer.

781

782 Priority Substances Under the Water Framework Directive. (2011). Available:

https://ec.europa.eu/environment/water/water-dangersub/pri substances.htm. $\quad$ Last

784 Accessed $27^{\text {th }}$ June 2018. 
Revitta, Lundy, L, Coulon, F. Fairley, M, 2014. The sources, impact and management of car park runoff pollution: A review. Journal of Environmental Management, Volume 146, pp. $552-567$.

Robinson M, Boardman J, Heppell K, Packman J, and Leeks G. (2000). Land Use Change. In: The Hydrology of the UK, M. Acreman (ed.). Routledge Publisher p.30 - 54.

Sahu, Ravi. \& Elumalai, S.P. (2017). Identifying Speed Hump, a Traffic Calming Device, as a Hotspot for Environmental Contamination in Traffic-Affected Urban Roads. ACS Omega. Vol. 2. pp. $5434-5444$.

Sansalone, J. J., Buchberger, S. G. and Al-Abed, S. R. (1996). Fractionation of Heavy Metals in Pavement Runoff. The Science of the Total Environment. Vol. 189/190. Pp.371-378.

Sebastiao, A.G, Wagner, E.J \& Goldsmith, S,T. (2017), Trace Metal Sediment Loading in the Mill Creek: A spatial and Temporal Analysis of Vehicular Pollutants in Suburban Waterways, Applied Geochemistry. Vol 83. pp.50-61.

Stucker, J.D. \& Lyons, W.B. 7th Dec 2016. Dissolved Trace Metals in Low-Order, Urban Stream Water, Columbus Ohio. Applied Geochemistry. 83. pp. 86 - 92.

Sutherland, R. A., and Tolosa, C. A. (2001). Variation in total and extractable elements with distance from roads in an urban watershed, Honolulu, Hawaii. Water Air Soil Pollut. Vol. 127, 315-338. 
811 Wang, Q., Zhang, Q., Dzakpasu, M., Chang, N. and Wang, X. (2019). Transferral of HMs 812 pollution from road-deposited sediments to stormwater runoff during transport processes. 813 Frontiers of Environmental Science and Engineering. Vol. 13. pp. 1 -13.

814

815

Wetroads. (2018). Wetroads.co.uk. Available at http://www.wetroads.co.uk/. Last accessed 816 3rd May 2018.

817

818 Wilson, M.C., Chen, X., Corlett, R.T. Didhem, R, K. Ding, P. Holt, R, D. Holyoak, M. Hu, G. 819 Highes, A, C. Jiang, L. Laurence, W,F. Liu, J. Pimm, S, L. Robinson, S,K. Russo, S, E. Si, X. 820 Wilcove, D,S. Wu, J and Yu, M. (2016) Habitat fragmentation and biodiversity conservation: key findings and future challenges. Landscape Ecology Vol. 31, pp. 219-227.

822

World Health Organisation (WHO). (2011). Guidelines for Drinking Water Quality (4 ${ }^{\text {th }}$ ed). Geneva: WHO.

825

826

World Health Organisation (WHO) (2001). Environmental Health Criteria 221: Zinc,

827 Vol 221. Geneva, WHO).

828

829 Wright, J.F., Sutcliffe, D.W. \& Furse, M.T. (1997). Assessing the Biological Quality of Fresh 830 Waters: RIVPACS and Other Techniques. Freshwater Biological Association. UK. 
832 Yao, Q.Z., Wang, X.J., Jian, H.M., Chen, H.T., Yu, Z.G., 2015. Behaviour of Suspended Particles 833 in the Changjiang Estuary: Size Distribution and Trace Metal Contamination. Marine 834 Pollution Bulletin 103 (1-2), pp.159-167. 


\begin{tabular}{|c|c|c|c|c|c|c|c|}
\hline Determinand & $\begin{array}{l}\text { Result } \\
\text { Range } \\
\text { (mg/kg) }\end{array}$ & $\begin{array}{l}\text { Results } \\
\text { Average } \\
\text { (mg/kg) }\end{array}$ & $\begin{array}{l}\text { Average } \\
\text { concntration } \\
\text { of control } \\
\text { Samples } \\
(\mathrm{mg} / \mathrm{kg})\end{array}$ & $\begin{array}{l}\text { Est. } \\
\text { Background } \\
\text { Geochemistry } \\
\text { Value (mg/kg) }\end{array}$ & $\begin{array}{l}\text { SGV } \\
(\mathrm{mg} / \mathrm{kg})\end{array}$ & C4SL/SSAC & $\begin{array}{l}\text { Human } \\
\text { Health } \\
\text { Exceedances }\end{array}$ \\
\hline Arsenic & $\begin{array}{l}3.0- \\
13.8\end{array}$ & 6.28 & 2.45 & $<15$ & & 32 & $\mathrm{~N}$ \\
\hline Cadmium & $\begin{array}{l}<0.5- \\
0.6\end{array}$ & - & Not tested $^{\ddagger}$ & 1.8 & & 5 & $\mathrm{~N}$ \\
\hline Chromium & $\begin{array}{l}4.0- \\
41.2\end{array}$ & 18.78 & 7.47 & $60-90$ & & 1950 & $\mathrm{~N}$ \\
\hline Copper & $\begin{array}{l}<5.0- \\
11.7\end{array}$ & 7.34 & 5.2 & - & & 5203 & $\mathrm{~N}$ \\
\hline Lead & $\begin{array}{l}7.2- \\
27.3 \\
\end{array}$ & 16 & 6.2 & $<100$ & 200 & & $\mathrm{~N}$ \\
\hline Magnesium & $\begin{array}{l}192- \\
6200\end{array}$ & 1186 & 297 & & & & - \\
\hline Manganese & $\begin{array}{l}137- \\
2370\end{array}$ & 773 & 57.1 & & & & - \\
\hline Mercury & $<0.5$ & BLOD $^{*}$ & $\begin{array}{l}\text { Not } \\
\text { Tested }^{\ddagger}\end{array}$ & & & 168 & $\mathrm{~N}$ \\
\hline Molybdenum & $<0.5$ & BLOD* & $\begin{array}{l}\text { Not } \\
\text { Tested }^{\ddagger}\end{array}$ & & & & \\
\hline Nickel & $\begin{array}{l}5.9- \\
40.1\end{array}$ & 17.34 & BLOD* & $15-30$ & & 533 & $\mathrm{~N}$ \\
\hline Zinc & $\begin{array}{l}31.6- \\
155.7\end{array}$ & 95.64 & 13.37 & & & 19400 & $\mathrm{~N}$ \\
\hline $\begin{array}{l}\text { Hexavalent } \\
\text { Chromium }\end{array}$ & $<0.8$ & BLOD* & $\begin{array}{l}\text { Not } \\
\text { Tested }^{\ddagger}\end{array}$ & & 21 & 21 & $\mathrm{~N}$ \\
\hline
\end{tabular}

*BLOD = Below Limit of Detection

\# Background levels not tested in control sample because sample point results were below detection limit

Table 1: Average Results of Concentrations within Bed Sediments compared to Human Health Criteria

\begin{tabular}{|c|c|c|c|c|}
\hline \multirow{2}{*}{ Determinand } & \multicolumn{3}{|c|}{ Phytotoxicity GAC (mg/kg) } & \multirow{2}{*}{ GAC Exceedances } \\
\cline { 2 - 5 } & $\mathrm{pH}<6.0$ & $\mathrm{pH} 6.0-7.0$ & $\mathrm{pH}>7.0$ & No \\
\hline Zinc & 200 & 200 & 300 & No \\
\hline Copper & 100 & 135 & 200 & No \\
\hline Nickel & 60 & 75 & 110 & \\
\hline
\end{tabular}

Table 2: Summary of Plant Phytotoxicity Assessment No exceedances of Generic Assessment Criteria for $\mathrm{Zn}, \mathrm{Cu}$ and $\mathrm{Ni}$ were identified within the stream sediments. 

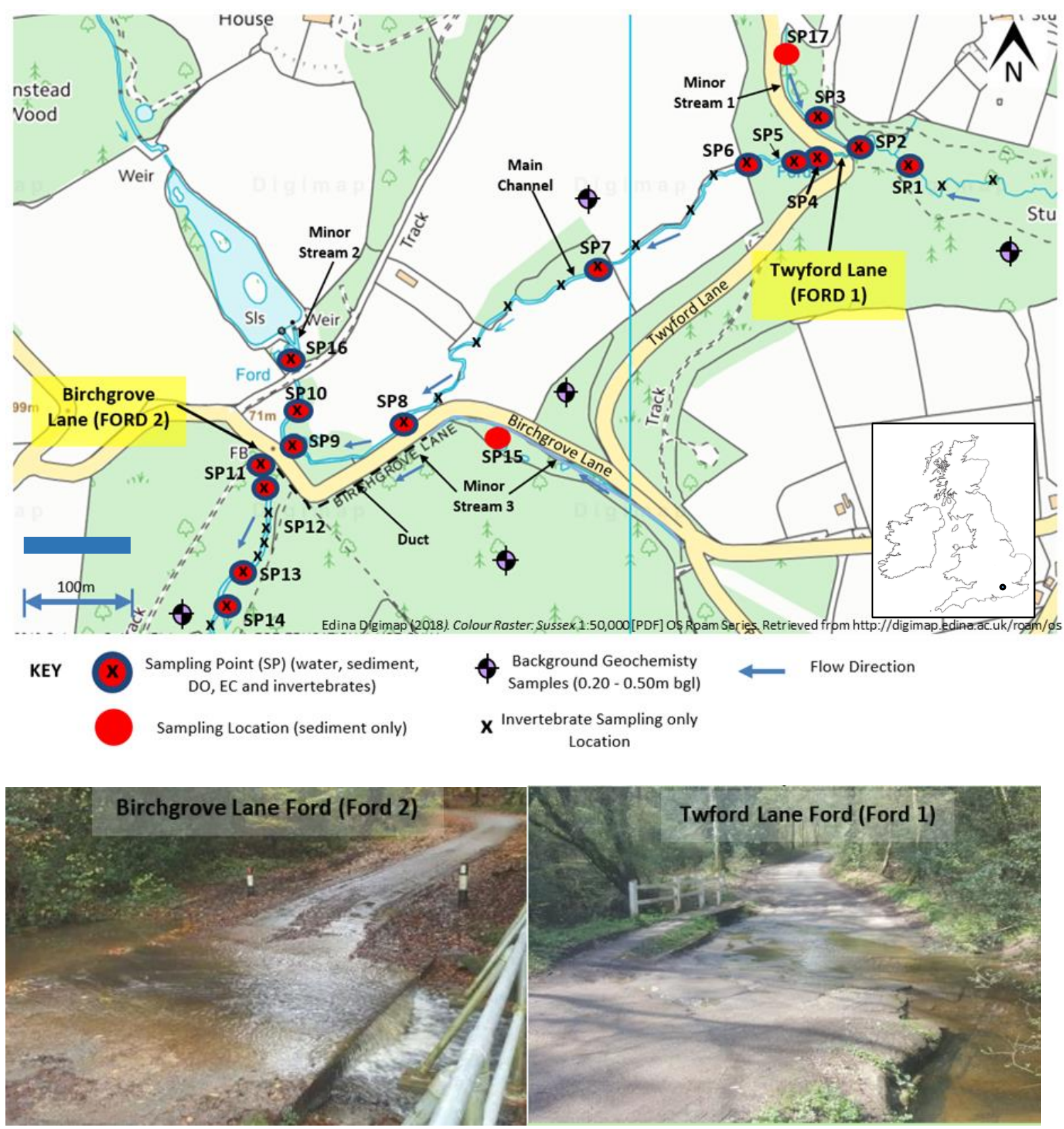

Figure 1: The study area along with photo-view of fords and sampling sites across the fords. The area occupies a section of a tributary of the River Ouse, located in a shallow valley of forest and agrarian land in Sussex. The tributary is joined (immediately upstream of the fords) by two minor channels (Minor Stream 1 \& 2 ), one at each ford. Another minor stream (Minor Stream 3), cutting into the roadside, runs alongside Birchgrove Lane joining the tributary immediately downstream of Ford 2. Both, Minor Streams $1 \&$ \&, are ephemeral and were dry on several visits. Ref: Edina Digimap (2018). Colour Raster: Sussex 1:50,000 [PDF] OS Roam Series. Retrieved from http://digimap.edina.ac.uk/roam/os 


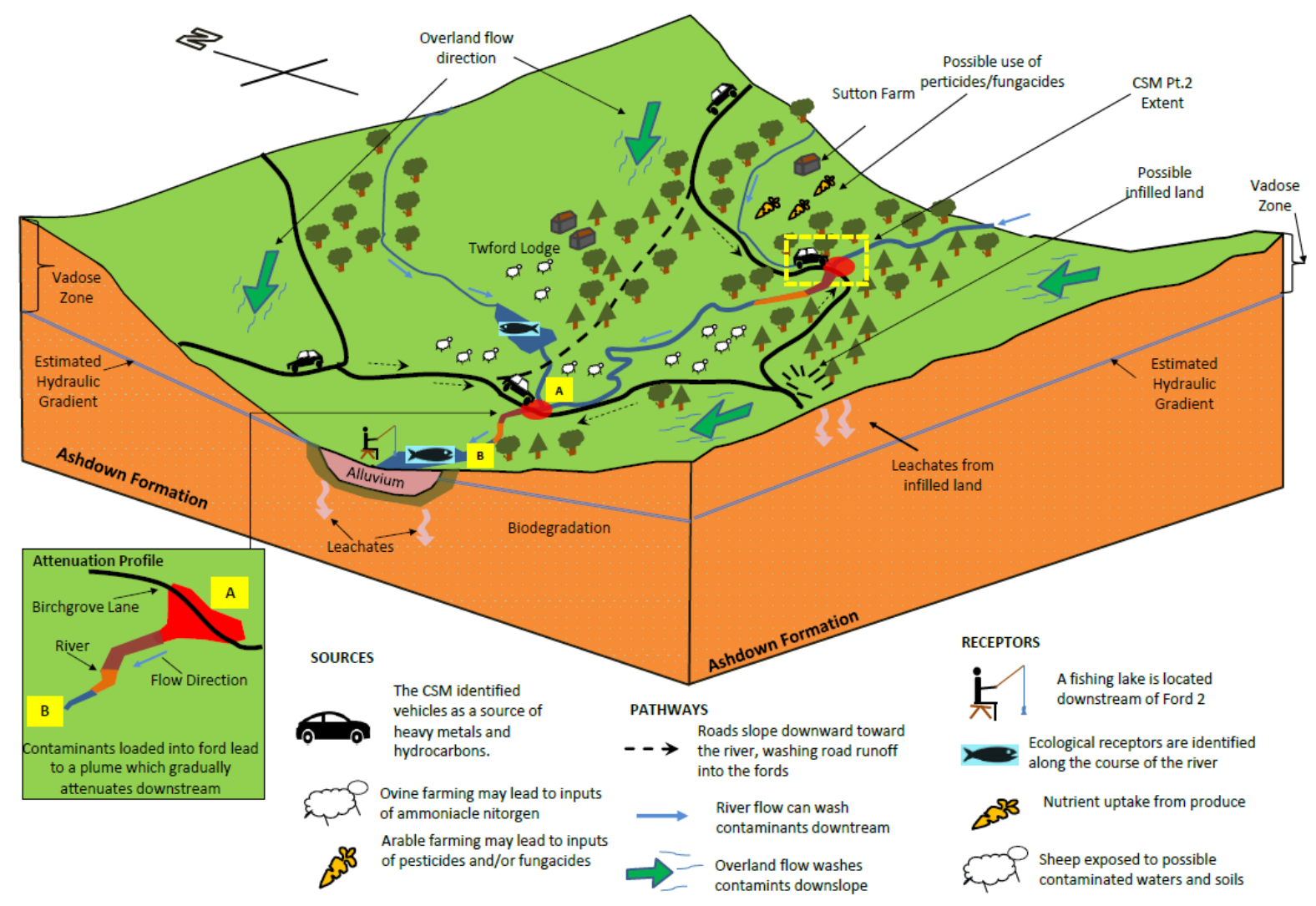

Figure 2: A conceptual site model of the study area illustrating the risk rendering from potential source-pathways-receptor interaction. Topography and land use make the tributary and stream network vulnerable to contamination from various sources. 

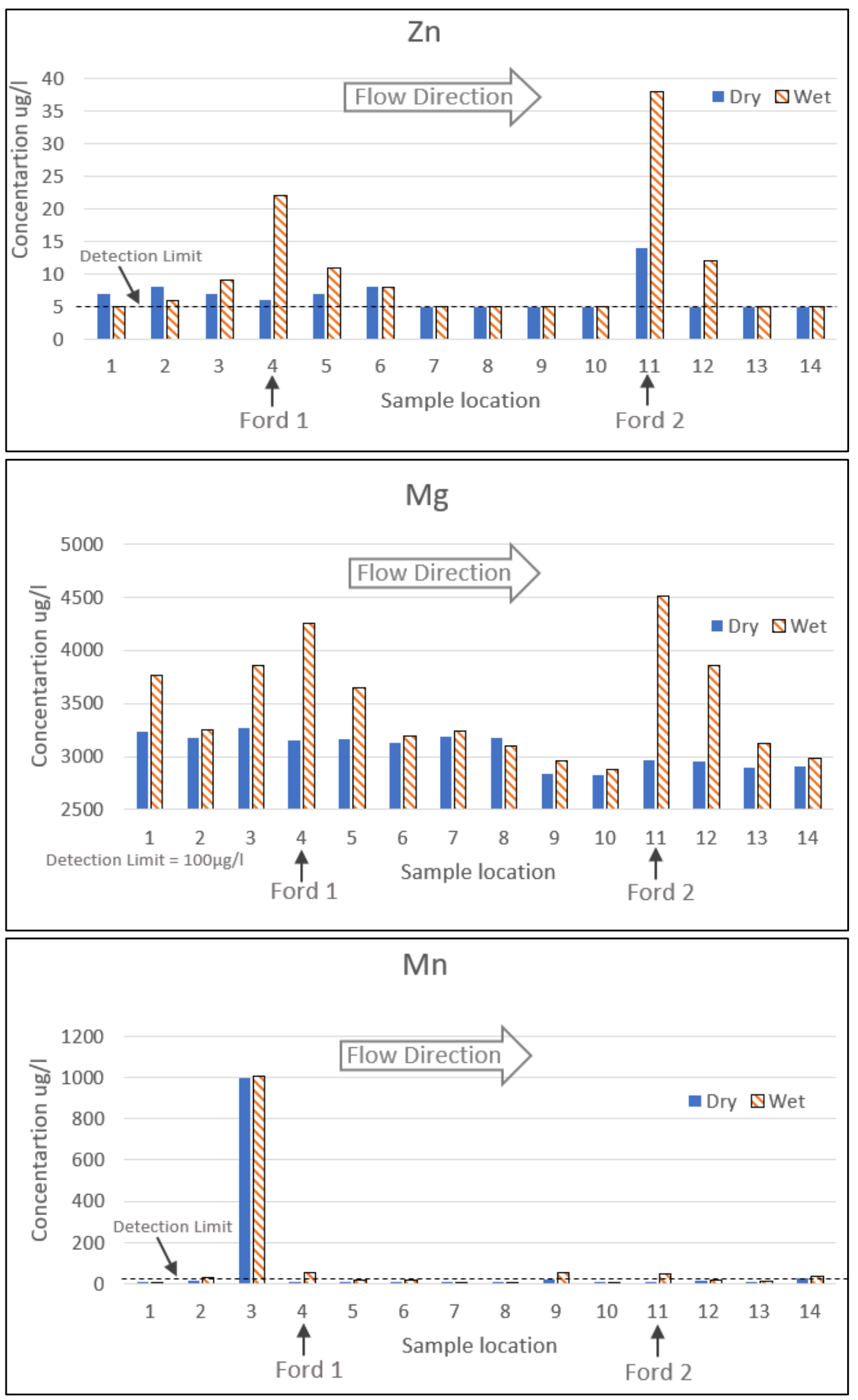

Figure 3: Metal Concentrations in Water: $\mathrm{Zn}, \mathrm{Mg}$ and $\mathrm{Mn}$ are the elements that were found to occur at high concentrations. The arrows at the bottom of each graph represent where the ford locations are, samples 4 and 11 are taken immediately downstream of Ford 1 and Ford 2 respectively 


\begin{tabular}{|l|c|c||c|c||c|c|}
\cline { 2 - 7 } \multicolumn{1}{c|}{} & \multicolumn{2}{c||}{ Control Samples } & \multicolumn{2}{c||}{ Twyford Lane (Ford 1) } & \multicolumn{2}{c|}{ Birch Grove Lane (Ford 2) } \\
\cline { 2 - 7 } \multicolumn{1}{c|}{} & $\begin{array}{c}\text { Range } \\
(\mathrm{mg} / \mathrm{kg})\end{array}$ & $\begin{array}{c}\text { Average } \\
(\mathrm{mg} / \mathrm{kg})\end{array}$ & $\begin{array}{c}\text { Range } \\
(\mathrm{mg} / \mathrm{kg})\end{array}$ & $\begin{array}{c}\text { Average } \\
(\mathrm{mg} / \mathrm{kg})\end{array}$ & $\begin{array}{c}\text { Range } \\
(\mathrm{mg} / \mathrm{kg})\end{array}$ & $\begin{array}{c}\text { Average } \\
(\mathrm{mg} / \mathrm{kg})\end{array}$ \\
\hline Arsenic & $1.8-3.8$ & 2.45 & $3.7-11.2$ & 6.7 & $3.0-8.0$ & 5.16 \\
\hline Chromium & $<5-11.1$ & 7.47 & $23.4-34.5$ & 28.5 & $33.2-41.2$ & 37.0 \\
\hline Copper & $<5-6.2$ & 5.2 & $<5-8.1$ & 6.43. & $6.3-11.7$ & 9.4 \\
\hline Lead & $5.2-7.2$ & 6.2 & $14.2-18.2$ & 16.48 & $19.8-27.3$ & 23.8 \\
\hline Magnesium & $295-356$ & 297 & $192-1010$ & 496 & $1630-6200$ & 3218 \\
\hline Manganese & $40.5-153$ & 57.1 & $138-567$ & 354 & $561-1790$ & 1003 \\
\hline Nickel & $<5$ & - & $19.6-35.0$ & 24.97 & $8.2-12.7$ & 11.65 \\
\hline Zinc & $11.5-19.3$ & 13.37 & $98.6-155.7$ & 134.28 & $98.8-144.4$ & 121.13 \\
\hline
\end{tabular}

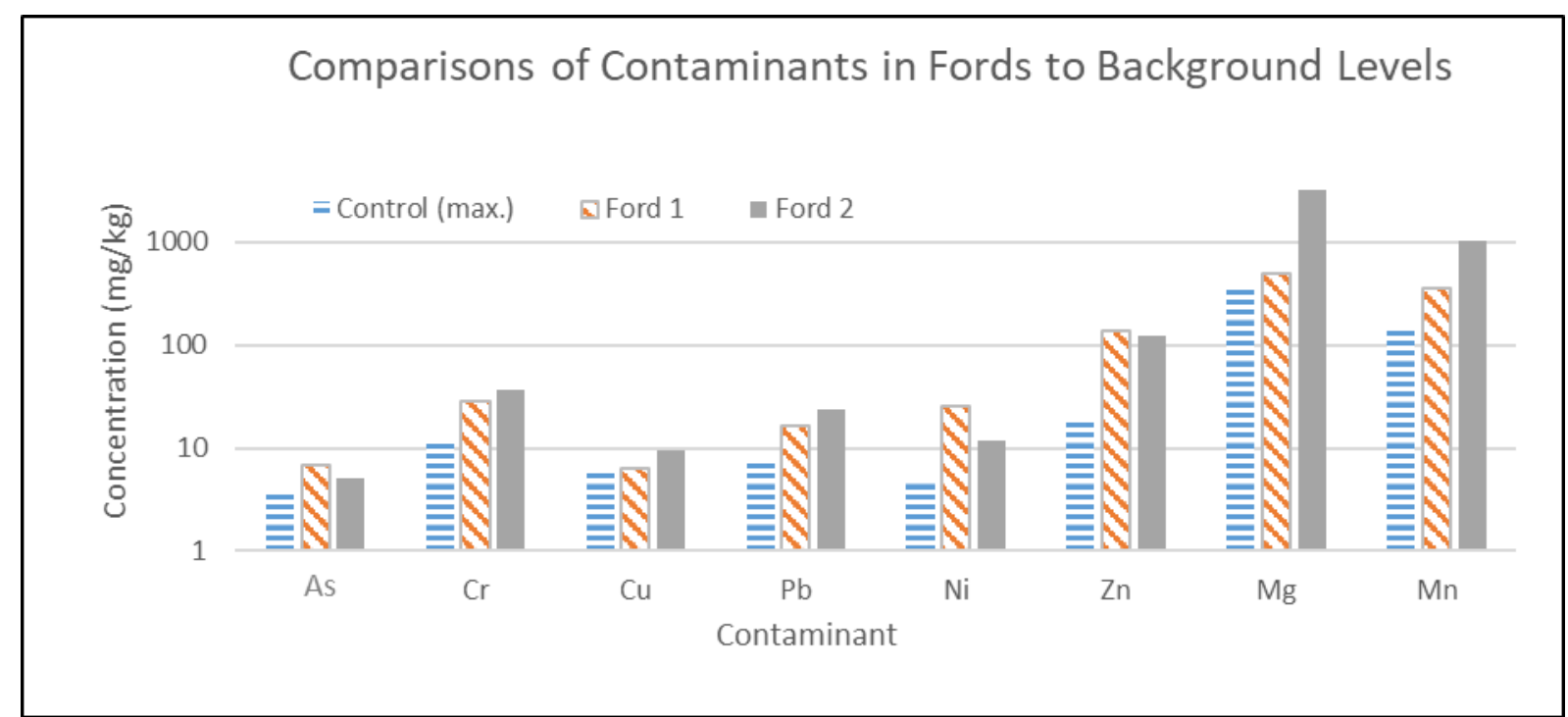

Figure 4: Comparison of Background and Ford Contaminant Concentrations (Base 10 Log Scale). The control sample results were compared to the sediment samples taken from within the stream. The concentrations of elements shown above highlight that elemental concentrations are consistently elevated in the ford crossings compared to concentrations within the control samples. 

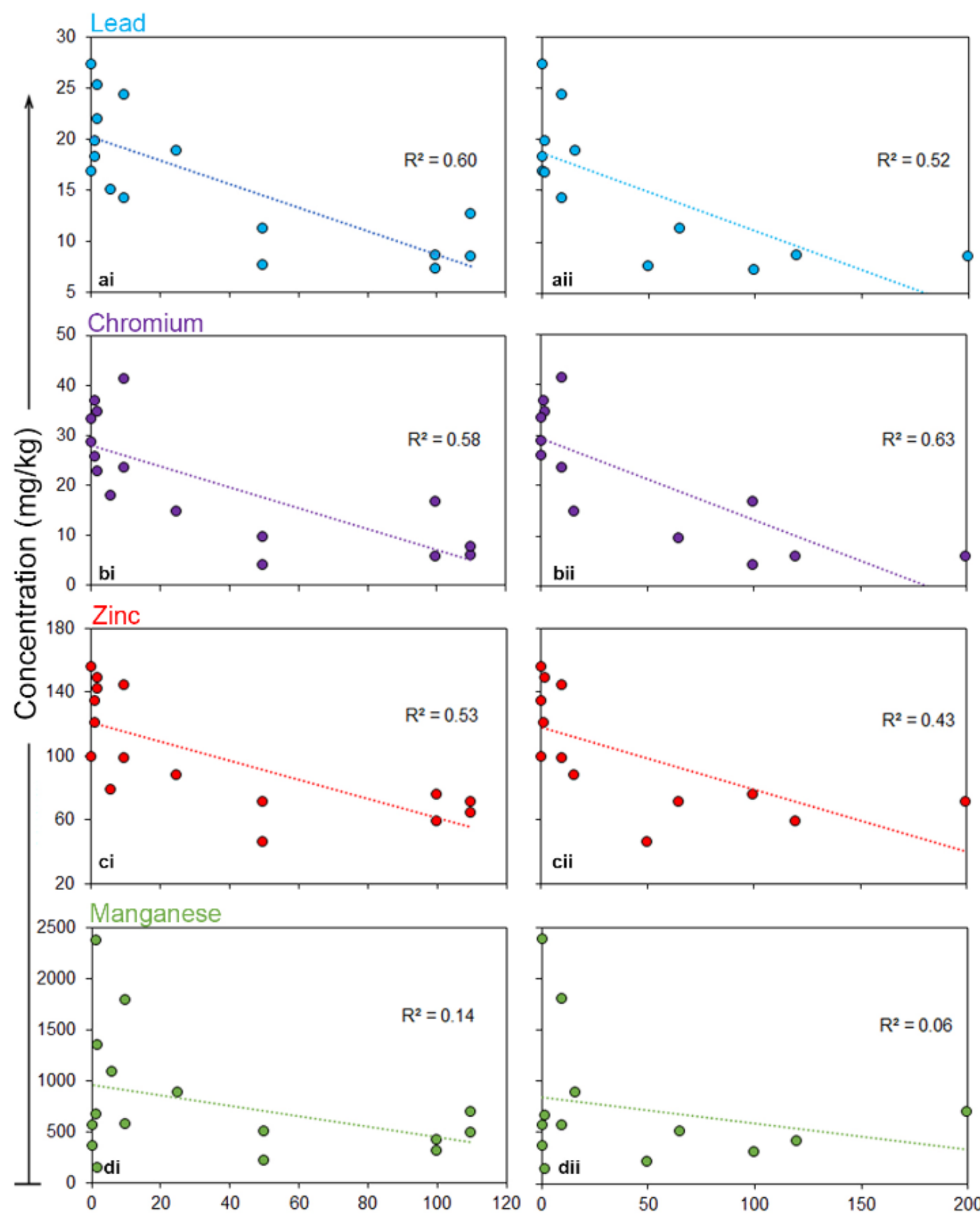

Distance from Road (m)

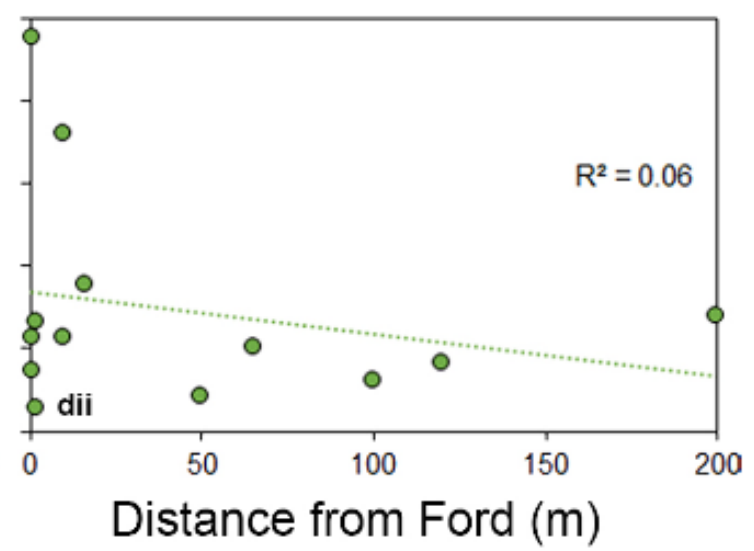

Figure 5: Contaminants Vs Road Distance and Ford Distance. An inverse association between the concentration of elements and distances from the road and fords was identified. 

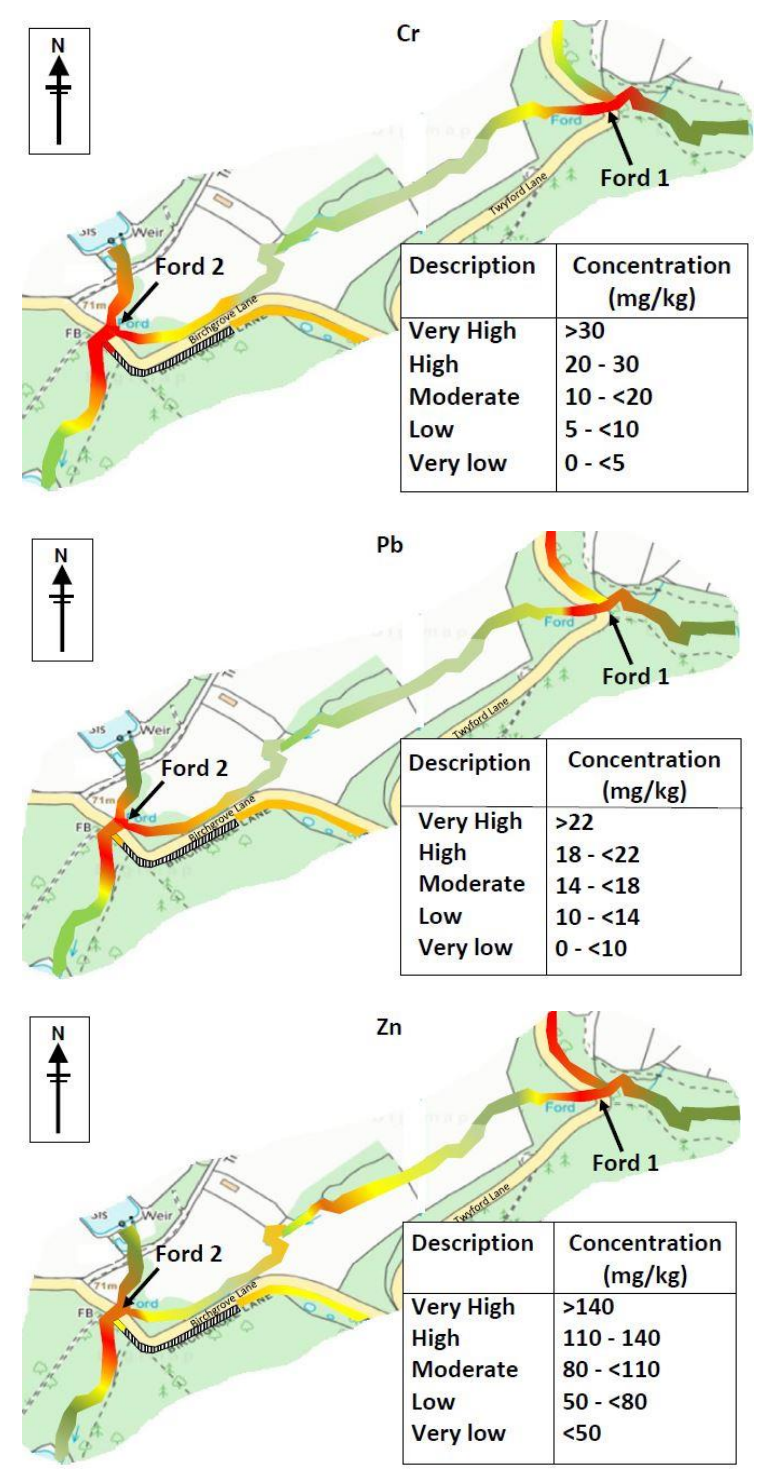

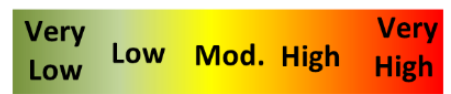

Figure 6: Spatial Distributions of Chromium, Lead and Zinc: Note: The Scale is Comparable to background Readings Identified in Fig. 4. The spatial diagram shows highest concentrations for $\mathrm{Cr}, \mathrm{Pb}$ and $\mathrm{Zn}$ immediately downstream of the ford crossings. 

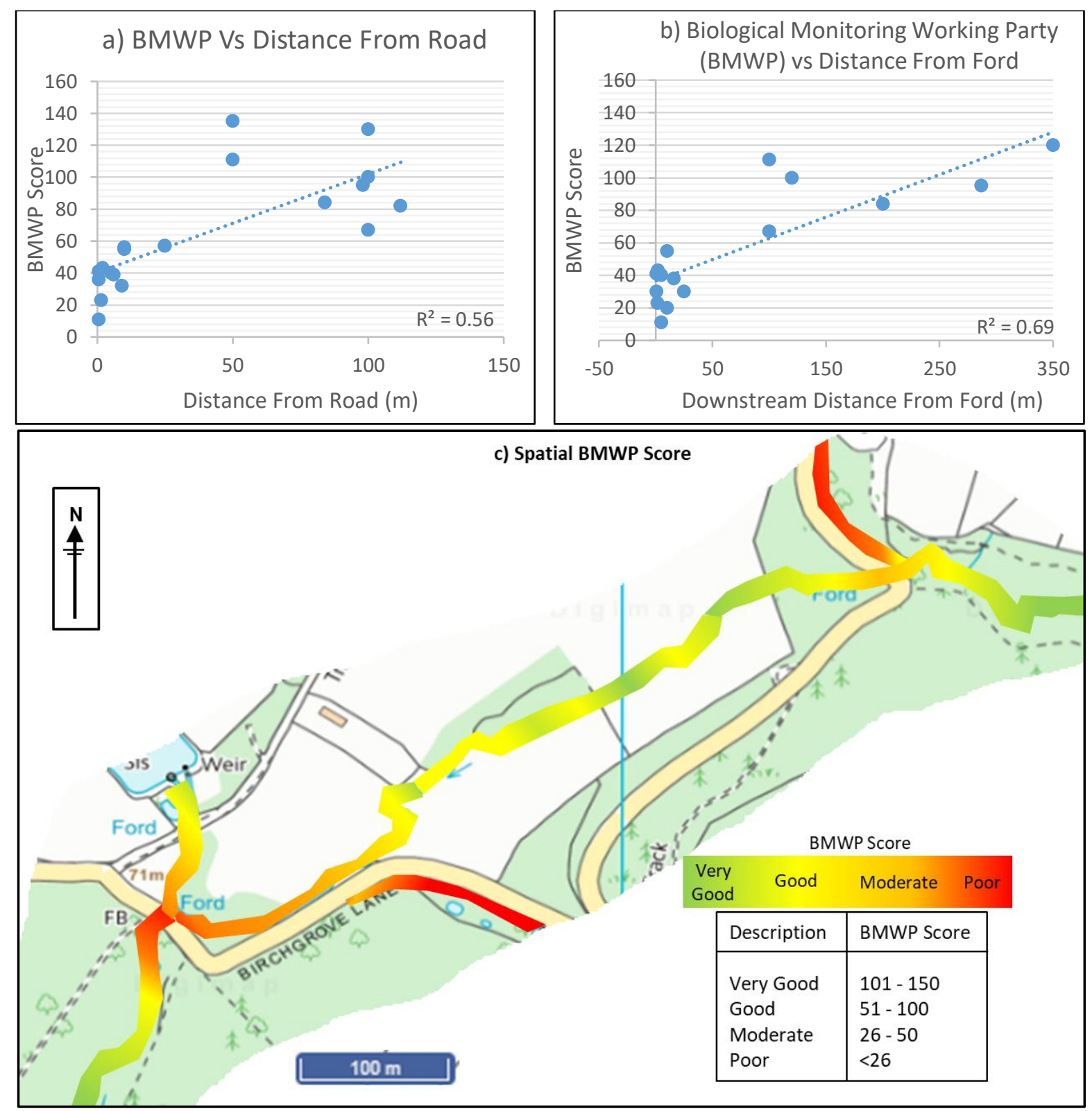

Figure 7: BMWP Score Vs Road Distance (a) and BMWP Score Vs Ford Distance (b) Spatial

Distribution of BMWP Scores (c): 7a): A strong negative correlation between BMWP score and distance from the road is identified by an $R^{2}$ value of 0.56 . 7b): A significant correlation between increased distance from the ford crossing and increased BMWP score with and $R^{2}$ value of 0.69, further backed up by a Pearson's coefficient of 0.72. 7c): In general, BMWP scores are lower ("moderate" to "poor") in, and in proximity to, the ford crossings. "Very Good" scores are recorded with increased distances from the ford. 


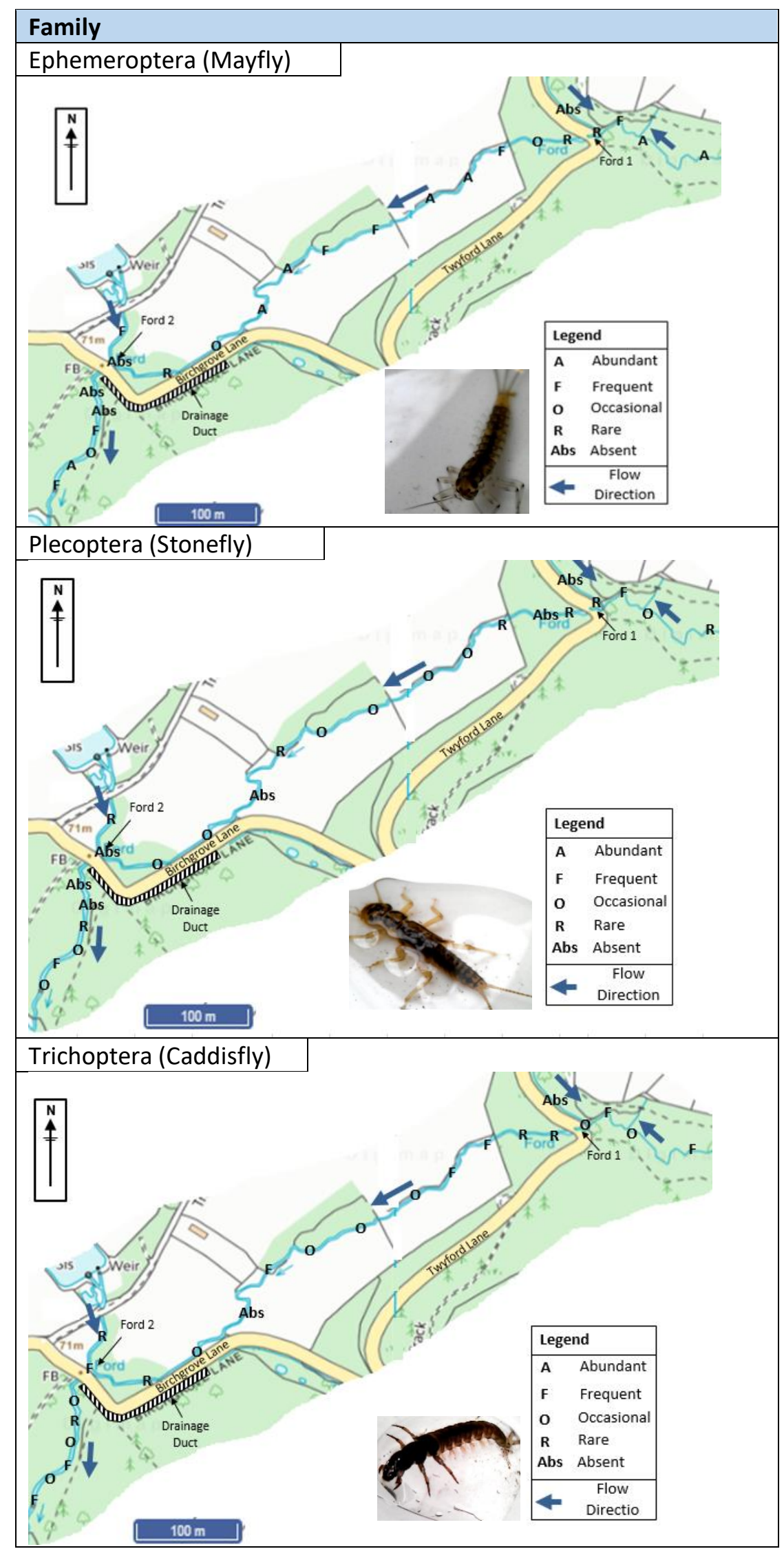

Figure 8 Invertebrate Abundance. Ephemeroptera and plecopteran are noted as being rare in Ford 1 and absent in Ford 2. Conversely, Ephemeroptera are noted as being frequent or abundant in sampling positions away from the ford crossings and road, whilst Plecoptera are recorded as being occasional further from the fords and roads. A slightly different pattern was observed for the less sensitive Trichoptera, which was found to be "occasional at Ford 1 and "frequent" at Ford 2. 

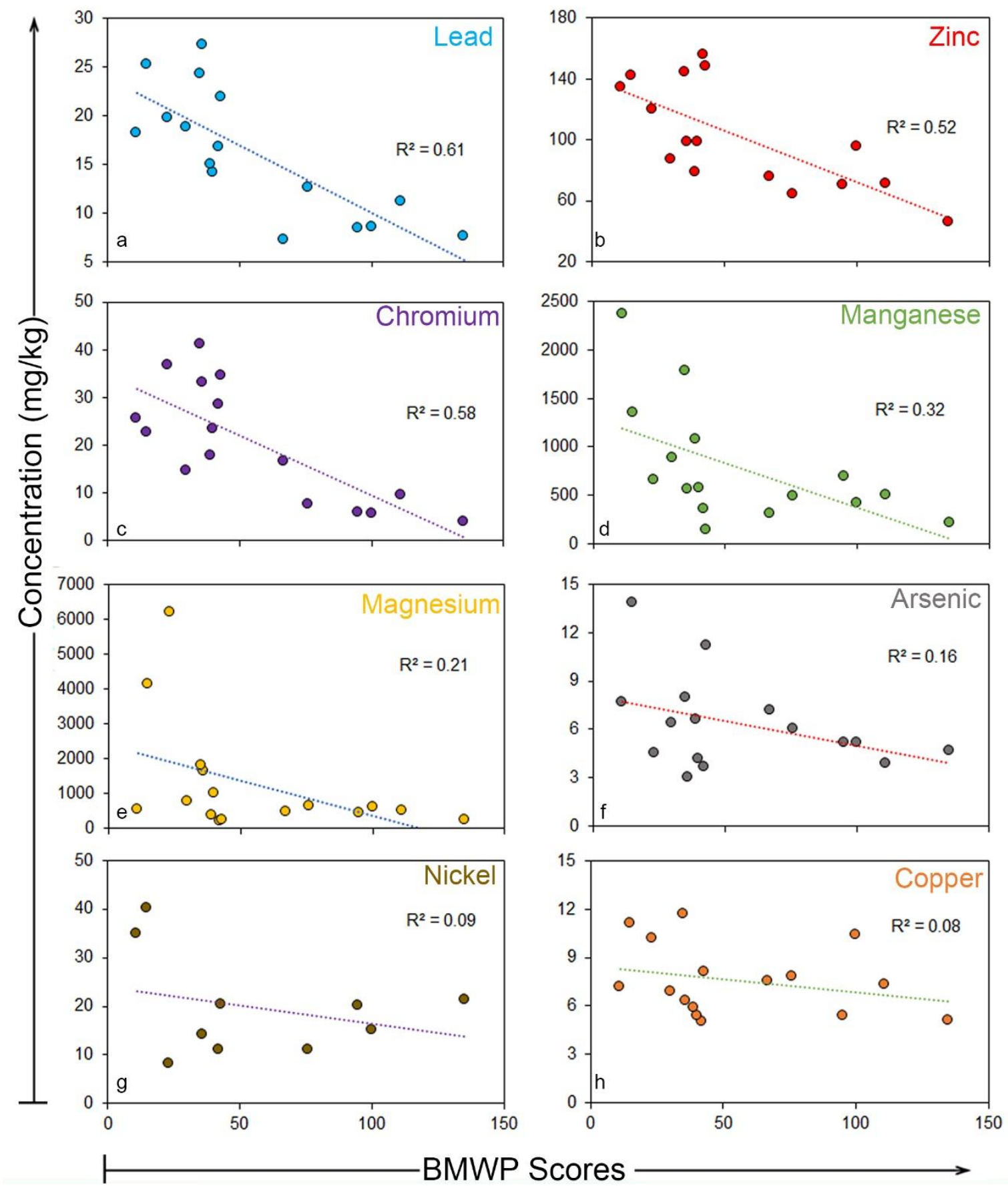

Figure 9: Metals Vs BMWP Scores: $\mathrm{Cr}, \mathrm{Pb}$ and $\mathrm{Zn}$ and to a lesser extent $\mathrm{Cu}, \mathrm{Ni}, \mathrm{Mn}$ and $\mathrm{Mg}$, have a negative influence on BMWP scores. 


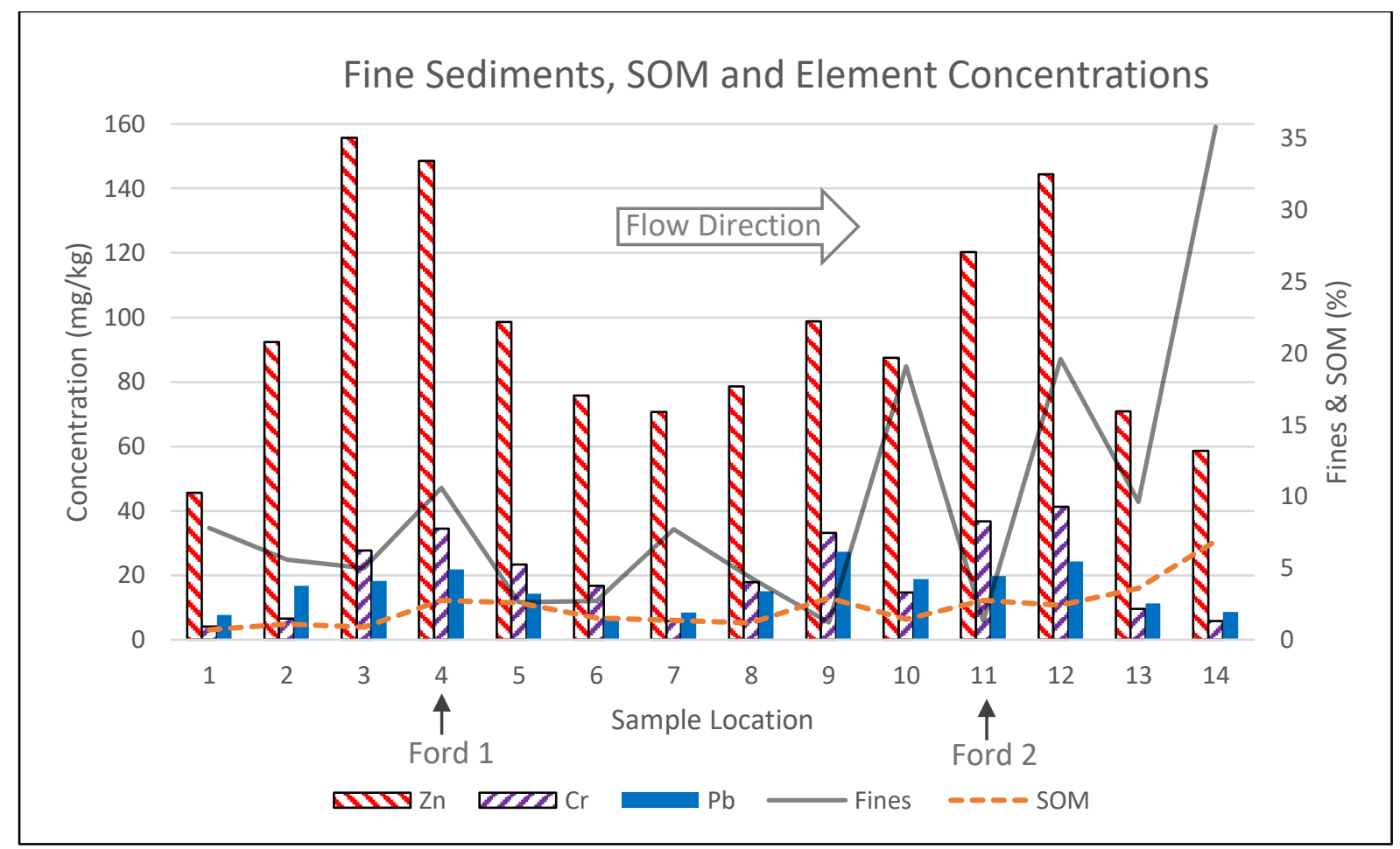

Figure 10: Relationship Between Particle Size, SOM and Elemental Concentration 

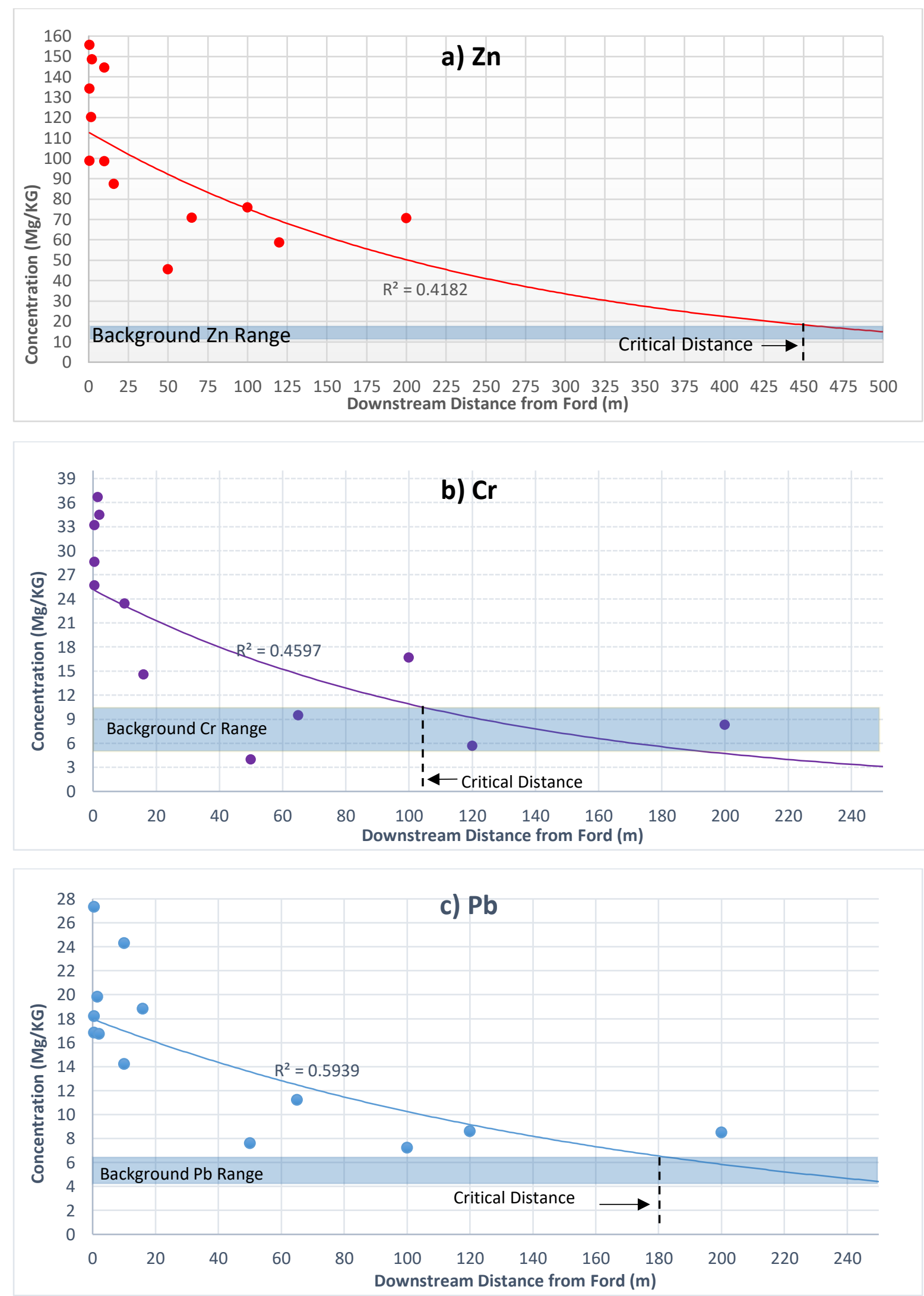

Figure 11: Estimated downstream attenuation distances (i.e. distance to return to background range) for $\mathrm{Zn}, \mathrm{Cr}$ and $\mathrm{Pb}$. $\mathrm{Zn}$ is estimated to not return within the normal background range until ca.450m downstream of a ford. The critical distances for $\mathrm{Cr}$ and $\mathrm{Pb}$ are ca.106m \& ca.180m respectively. 


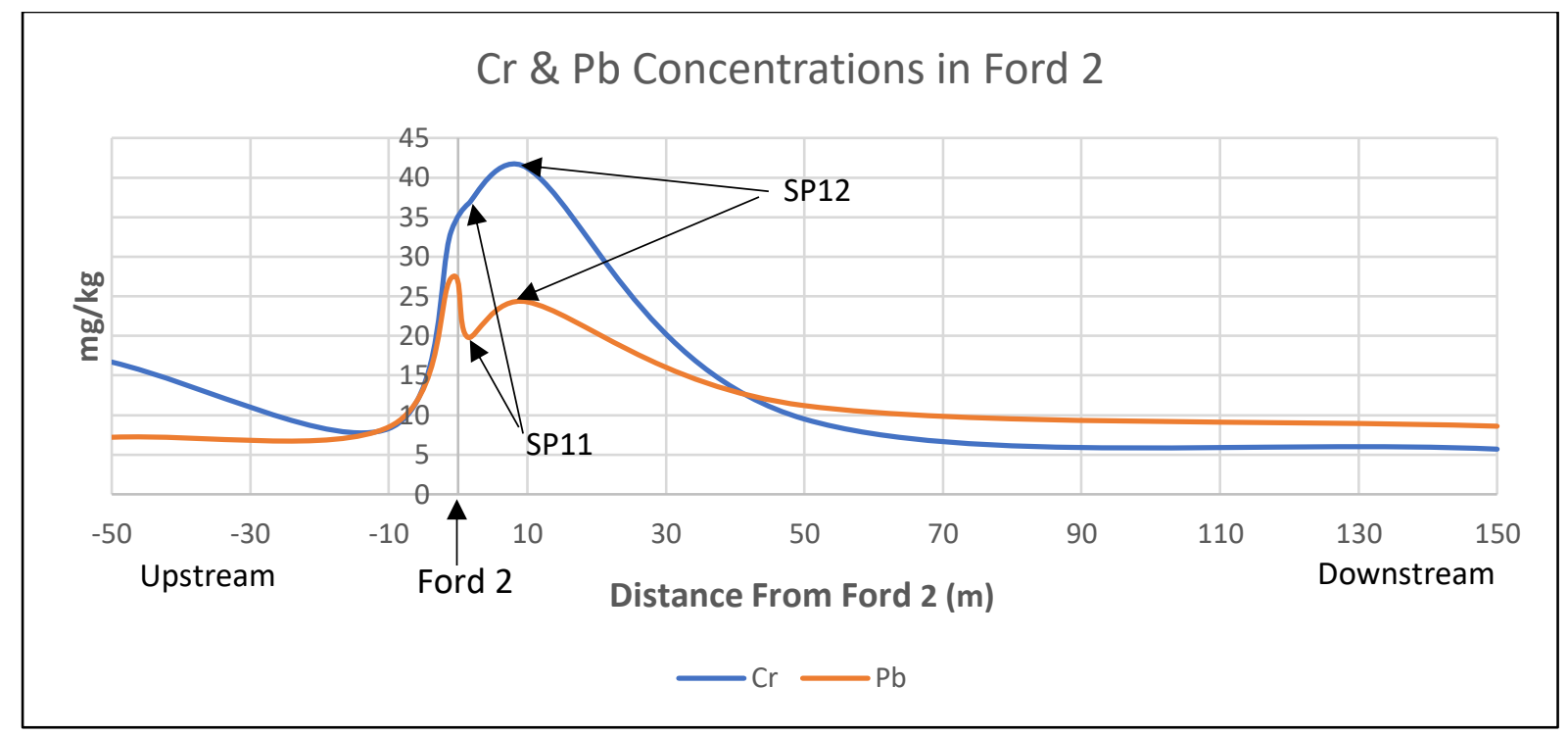

Figure 12: Concentrations of $\mathrm{Pb}$ and $\mathrm{Cr}$ at sample points near to Ford 2: Higher concentrations of some elements were recorded at SP12 (10m downstream from Ford 2) than they were at SP11 (located immediately downstream of Ford 2). For example, $\mathrm{Pb}$ and $\mathrm{Cr}$ concentrations at SP11 were $19.8 \mathrm{mg} / \mathrm{kg}$ and $36.7 \mathrm{mg} / \mathrm{kg}$ respectively. Whereas at SP12, where slightly lower concentrations would be expected, concentrations were $24.3 \mathrm{mg} / \mathrm{kg}$ and $41.2 \mathrm{mg} / \mathrm{kg}$ respectively. The concentrations then regress further downstream at SP13 and SP14.

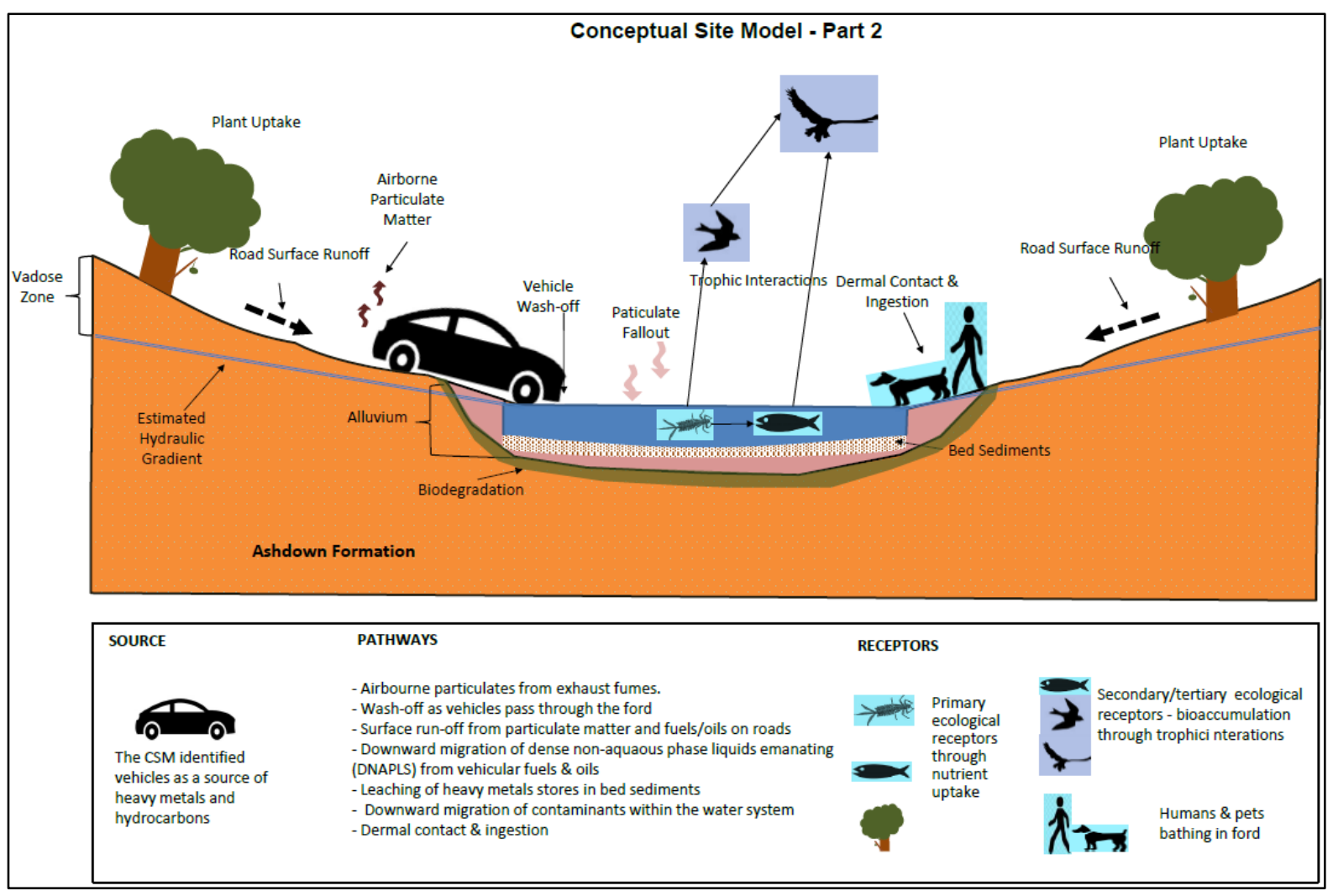

Figure 13: Overall Conceptual Contamination Model: Illustration the mechanism of contamination by vehicular wash off and influence of topography and road wash off, immediately after rainfall/precipitation event. 